\title{
Neuromodulatory Action of Picomolar Extracellular A $\beta 42$ Oligomers on Presynaptic and Postsynaptic Mechanisms Underlying Synaptic Function and Memory
}

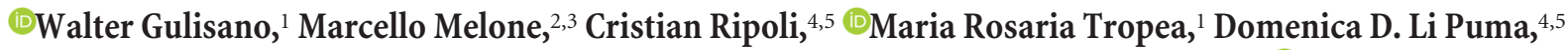 \\ Salvatore Giunta, ${ }^{1}$ Sara Cocco, ${ }^{4}$ Daniele Marcotulli, ${ }^{2}$ Nicola Origlia, ${ }^{6}$ Agostino Palmeri, ${ }^{1}{ }^{\circledR 0}$ Ottavio Arancio, ${ }^{7}$ \\ Fiorenzo Conti, ${ }^{2,3,8}$ @Claudio Grassi, ${ }^{4,5}$ and $\odot$ Daniela Puzzo ${ }^{1,9}$ \\ ${ }^{1}$ Department Biomedical and Biotechnological Sciences, University of Catania, Catania 95123, Italy, ${ }^{2}$ Section of Neuroscience and Cell Biology, Department \\ Experimental and Clinical Medicine, Università Politecnica delle Marche, Ancona 60020, Italy, ${ }^{3}$ Center for Neurobiology of Aging, IRCCS Istituto Nazionale \\ Ricovero e Cura Anziani (INRCA), Ancona 60020, Italy, ${ }^{4}$ Institute of Human Physiology, Università Cattolica del Sacro Cuore, Rome 00168, Italy, \\ ${ }^{5}$ Fondazione Policlinico Universitario A. Gemelli IRCCS, Rome 00168, Italy, ${ }^{6}$ Neuroscience Institute, Italian National Research Council, Pisa 56100, Italy, \\ ${ }^{7}$ Taub Institute for Research on Alzheimer's Disease and the Aging Brain, Columbia University, New York, New York 10032, ${ }^{8}$ Foundation for Molecular \\ Medicine, Università Politecnica delle Marche, Ancona 60020, Italy, and ${ }^{9}$ Oasi Research Institute-IRCCS, Troina, 94018, Italy
}

Failure of anti-amyloid- $\beta$ peptide $(\mathrm{A} \beta$ ) therapies against Alzheimer's disease $(\mathrm{AD})$, a neurodegenerative disorder characterized by high amounts of the peptide in the brain, raised the question of the physiological role of $\mathrm{A} \beta$ released at low concentrations in the healthy brain. To address this question, we studied the presynaptic and postsynaptic mechanisms underlying the neuromodulatory action of picomolar amounts of oligomeric $\mathrm{A} \beta_{42}\left(\mathrm{oA} \beta_{42}\right)$ on synaptic glutamatergic function in male and female mice. We found that $200 \mathrm{pm} 0 \mathrm{~A} \beta_{42}$ induces an increase of frequency of miniature EPSCs and a decrease of paired pulse facilitation, associated with an increase in docked vesicle number, indicating that it augments neurotransmitter release at presynaptic level. $\mathrm{oA} \beta_{42}$ also produced postsynaptic changes as shown by an increased length of postsynaptic density, accompanied by an increased expression of plasticity-related proteins such as cAMPresponsive element binding protein phosphorylated at Ser133, calcium-calmodulin-dependent kinase II phosphorylated at Thr286, and brain-derived neurotrophic factor, suggesting a role for A $\beta$ in synaptic tagging. These changes resulted in the conversion of early into late long-term potentiation through the nitric oxide/cGMP/protein kinase $\mathrm{G}$ intracellular cascade consistent with a cGMP-dependent switch from short- to long-term memory observed in vivo after intrahippocampal administration of picomolar amounts of oA $\beta_{42}$. These effects were present upon extracellular but not intracellular application of the peptide and involved $\alpha 7$ nicotinic acetylcholine receptors. These observations clarified the physiological role of $\mathrm{oA} \beta_{42}$ in synaptic function and memory formation providing solid fundamentals for investigating the pathological effects of high $\mathrm{A} \beta$ levels in the $\mathrm{AD}$ brains.

Key words: amyloid precursor protein; amyloid-beta oligomers; neurotransmitter release; nicotinic receptors; synaptic plasticity; synaptic transmission

Significance Statement

High levels of oligomeric amyloid- $\beta_{42}\left(\mathrm{oA} \beta_{42}\right)$ induce synaptic dysfunction leading to memory impairment in Alzheimer's disease (AD). However, at picomolar concentrations, the peptide is needed to ensure long-term potentiation (LTP) and memory. Here, we show that extracellular 200 рм оА $\beta_{42}$ concentrations increase neurotransmitter release, number of docked vesicles, postsynaptic density length, and expression of plasticity-related proteins leading to the conversion of early LTP into late LTP and of short-term memory into long-term memory. These effects require $\alpha 7$ nicotinic acetylcholine receptors and are mediated through the nitric oxide/cGMP/protein kinase $\mathrm{G}$ pathway. The knowledge of $\mathrm{A} \beta$ function in the healthy brain might be useful to understand the causes leading to its increase and detrimental effect in AD. 


\section{Introduction}

Abnormal elevation of amyloid- $\beta$ peptide $(A \beta)$ in the brain is considered one of the main pathogenetic events in Alzheimer's disease (AD) (Hardy and Selkoe, 2002). Most of the studies in the field have focused on $\mathrm{A} \beta$ production, aggregation, and degradation, resulting in therapeutic strategies aimed at decreasing $A \beta$ levels in the brain. However, lack of correlation between insoluble $\mathrm{A} \beta$ deposits and cognitive impairment, presence of $\mathrm{A} \beta$ deposits in plaques or soluble oligomers in nondemented individuals (Aizenstein et al., 2008; Maarouf et al., 2011; Lesné et al., 2013), and failure of $\mathrm{A} \beta$-reducing therapies (Gulisano et al., 2018a) have prompted the neuroscience community to reconsider the pathogenetic role of the peptide (Herrup, 2015; Puzzo et al., 2015; Gulisano et al., 2018a). To this end, the concept that $A \beta$ is not solely a toxic product derived from amyloid precursor protein (APP) processing, already proposed in the early 1990s (Koo et al., 1993), has been strengthened by studies investigating the physiological role of the peptide in the CNS. Nonetheless, information regarding $A \beta$-dependent regulation of synaptic activity in the healthy brain is still fragmentary, precluding a clear insight into the mechanisms underlying the switch from function to dysfunction (Koppensteiner et al., 2016).

In addition to its neuroprotective activity (Pearson and Peers, 2006), $\mathrm{A} \beta$ is likely to act as a neuromodulator at the synapse, where it is released during neuronal activity (Kamenetz et al., 2003; Brody et al., 2008) and is dynamically regulated by presynaptic mechanisms involving vesicle cycling (Cirrito et al., 2005, 2008 ). Our previous studies have shown that $A \beta$ production increases during the induction of long-term potentiation (LTP) (Palmeri et al., 2017) and contextual fear learning (Puzzo et al., 2011) and that blocking its function in the healthy brain impairs LTP and memory (Garcia-Osta and Alberini, 2009; Morley et al., 2010; Puzzo et al., 2011). Moreover, administration of picomolar concentrations of the peptide, mimicking its physiological content in the brain (Schmidt et al., 2005; Puzzo et al., 2008), enhances LTP and memory (Puzzo et al., 2008; Morley et al., 2010), suggesting that $\mathrm{A} \beta$ acts in a hormetic fashion exerting a biphasic effect depending upon its concentration (Puzzo et al., 2012).

Recently, we have demonstrated that both the positive and negative effects exerted by $\mathrm{A} \beta_{42}$ at the synapse need the presence of oligomers (Gulisano et al., 2018b), suggesting that oligomeric $\mathrm{A} \beta_{42}\left(\mathrm{oA} \beta_{42}\right)$ plays a key role in physiological synaptic function. These findings prompted us to investigate in depth how picomolar concentrations of oA $\beta_{42}$ affect the presynaptic and postsynaptic mechanisms underlying synaptic transmission and plasticity, as well as memory, highlighting similarities and differences between the physiological and pathological roles of the peptide.

\footnotetext{
Received Jan. 19, 2019; revised April 9, 2019; accepted April 28, 2019.

Author contributions: W.G., M.M., C.R., O.A., F.C., C.G., and D.P. designed research; W.G., M.M., C.R., M.R.T., D.D.L.P., S.G., S.C., N.O., and D.P. performed research; W.G., M.M., C.R., M.R.T., D.D.L.P., S.G., S.C., D.M., and D.P. analyzed data; W.G., M.M., C.R., M.R.T., D.D.L.P., S.C., D.M., N.O., A.P., O.A., F.C., C.G., and D.P. edited the paper; O.A., F.C., C.G., and D.P. wrote the paper; D.P. wrote the first draft of the paper.

This work was supported by Alzheimer's Association (IIRG-09-134220 to D.P. and NIRG-14-321307 to C.R.), University of Catania (Bando Chance to A.P. and D.P.), Italian Ministry of University and Research (PRIN 2010-JFYFY2 to F.C.), INRCA IRCCS (intramural funds to F.C.), NIH (NS-049442 and AG034248 to 0.A.).

The authors declare no competing financial interests.

Correspondence should be addressed to Daniela Puzzo at danypuzzo@yahoo.it.

https://doi.org/10.1523/JNEUROSCI.0163-19.2019

Copyright $\odot 2019$ the authors
}

\section{Materials and Methods}

Ethical approval

All experiments involving animals were approved by the University of Catania (\#327/2013-B, \#119-2017-PR) and the Università Cattolica del Sacro Cuore in Rome (\#626-2016-PR) in accordance with the respective regulations of local Institutional Animal care and Use Committee and with European Union Directive 2010/63/EU. The experiments complied with the ARRIVE guidelines and were conducted to minimize the animals' pain and suffering.

\section{Animals}

WT (C57BL/6); RRID:IMSR_JAX:000664), App-KO (B6.129S7-App ${ }^{\text {tm1Dbo } / J ; ~}$ RRID:IMSR_JAX:004133) and $\alpha 7-\mathrm{KO}$ (B6.129S7-Chrna7 ${ }^{\text {tmlBay } / J ; ~ R R I D: ~}$ IMSR_JAX:003232) mice were purchased from The Jackson Laboratory and bred in the animal facilities at University of Catania and Università Cattolica del Sacro Cuore. Mice were maintained in stable hygrometric and thermic conditions $\left(50 \% ; 21^{\circ} \mathrm{C} \pm 1{ }^{\circ} \mathrm{C}\right)$ on $12 \mathrm{~h}$ light/dark cycle with ad libitum access to food and water. For electrophysiological recordings, male animals were used at 3-4 months of age (field recordings) or $21 \mathrm{~d}$ (whole-cell recordings). Dual patch-clamp recordings experiments were performed on organotypic slices from P4-P7 Wistar rats. For behavioral experiments, sex-balanced groups of mice were used at 3-4 months of age.

\section{A $\beta$ preparation, concentration, and characterization}

Oligomeric $\mathrm{A} \beta$ was prepared as described previously (Stine et al., 2003; Puzzo et al., 2008; Ripoli et al., 2013). Briefly, the lyophilized peptide (American Peptide) was suspended in 1,1,1,3,3,3-hexafluoro-2propanol (HFIP; Sigma-Aldrich) to $1 \mathrm{~mm}$. After the complete evaporation of HFIP to allow complete monomerization, the $\mathrm{A} \beta$ film was dissolved in dimethylsulfoxide (DMSO; Sigma-Aldrich), sonicated for $15 \mathrm{~min}$, aliquoted, and stored at $-20^{\circ} \mathrm{C}$. DMSO-A $\beta$ solution was incubated in PBS at $4^{\circ} \mathrm{C}$ for $12 \mathrm{~h}$ to allow oligomerization. The oligomerized $\mathrm{A} \beta$ solution was then diluted in ACSF or saline solution $(0.9 \% \mathrm{NaCl})$ to the final concentration, calculated based on the MW of the monomeric peptide.

Western blot of $200 \mathrm{pm}$ and $200 \mathrm{~nm} \mathrm{~A} \beta$ solutions was routinely performed to assess oligomers presence (Gulisano et al., 2018b). A $\beta$ solutions were incubated for $20 \mathrm{~min}$ at $29^{\circ} \mathrm{C}$ to reproduce the experimental conditions of electrophysiological experiments. After this step, NuPAGE LDS sample buffer $4 \times$ was added and $\mathrm{A} \beta$ preparations (at the final concentration of $200 \mathrm{~nm}$ and $200 \mathrm{pm}$ ) were separated on 10-20\% Novex Tricine precast gels (Invitrogen). Proteins were then transferred onto 0.2 $\mu \mathrm{m}$ nitrocellulose membranes (GE Healthcare) that were incubated overnight at $4^{\circ} \mathrm{C}$ with the mouse monoclonal antibody 6E10 (1:1000; Covance). The next day, membranes were revealed with HRPconjugated secondary antibodies (Cell Signaling Technology) using the SuperSignal West Femto Maximum Sensitivity Substrate (Thermo Fisher Scientific) and documented using an automated imaging system (UVItec, Cambridge Alliance). Low-range rainbow molecular weight markers (GE Healthcare Life Sciences) were used to assess the protein size.

Dose-response (DR) curves were performed to choose the dose of $\mathrm{A} \beta$ mimicking the physiological effects of oligomers on synaptic plasticity. Based on our previous work (Puzzo et al., 2012), hippocampal slices were treated with $\mathrm{A} \beta$ doses of 2, 20, and $200 \mathrm{pm}$ and 2, 20, and $200 \mathrm{~nm}$ for 20 min before to induce LTP. Based on these results, we used 200 pм A $\beta$ for in vitro experiments, corresponding to $0.903 \mathrm{pg}$ for in vivo injections into each hippocampus. DR curves were also performed with the same experimental design to assess the dose of $\mathrm{A} \beta$ capable of modifying paired-pulse facilitation (PPF).

\section{Drugs}

$N \omega$-nitro-L-arginine methyl ester hydrochloride (L-NAME, SigmaAldrich, $100 \mu \mathrm{M}$ ) (Johnstone and Raymond, 2011), 8- Bromoguanosine3', 5'- cyclic monophosphorothioate, Rp-isomer (Rp-8-Br-cGMPS, Biolog, $10 \mu \mathrm{m}$ for electrophysiology and $1 \mu \mathrm{g} / 1 \mu \mathrm{l}$ for behavioral studies) (Bollen et al., 2014), 1H-[1,2,4] oxadiazolo[4,3-a]quinoxalin-1-one (ODQ, Sigma-Aldrich, $100 \mu \mathrm{M}$ ) (Puzzo et al., 2005), anisomycin (ANI, Sigma-Aldrich, $20 \mu \mathrm{M}$ ) (Johnstone and Raymond, 2011) (2R)-amino-5- 
phosphonovaleric acid (APV, Tocris Bioscience, $50 \mu \mathrm{M}$ ) (Puzzo et al., 2008), and methyllycaconitine (MLA, Sigma-Aldrich, $10 \mu \mathrm{M}$ based on DR curves obtained in our laboratory) were dissolved in DMSO, aliquoted, and stored at $-20^{\circ} \mathrm{C}$. All drugs were diluted in ACSF or saline solution $(0.9 \% \mathrm{NaCl})$ to the desired final concentration right before electrophysiological or behavioral experiments. 6E10 (Covance, catalog \#SIG-39320, RRID:AB_662798, 1:300) and M3.2 (Covance, catalog \#SIG-39155, RRID:AB_2028758, $2 \mu \mathrm{g} / \mathrm{ml}$ ) antibodies used for electrophysiological experiments were directly diluted in ACSF according to previous studies (Ripoli et al., 2014; Palmeri et al., 2017).

\section{Dual whole-cell recordings}

Hippocampal organotypic slice cultures were prepared from $\mathrm{P} 4-\mathrm{P} 7$ rats through a McIllwain tissue chopper and placed on semiporous membranes (Millipore) for 5-7 d before recordings, as described previously (Spinelli et al., 2017). Hippocampal subfields and electrode positions were identified with the aid of $4 \times$ and $40 \times$ water-immersion objectives on an upright microscope equipped with differential interference contrast optics under infrared illumination (BX51WI; Olympus) and video observation (BTE-B050-U CMOS camera; Mightex). Neighboring pairs of pyramidal cells were recorded simultaneously in CA1 by single stimulating bipolar tungsten electrode (FHC) placed on the Schaffer collateral fibers, as described previously (Barone et al., 2019). Slices were incubated in artificial CSF (ACSF) containing the following (in mM): 119 $\mathrm{NaCl}, 2.5 \mathrm{KCl}, 4 \mathrm{CaCl}_{2}, 4 \mathrm{MgCl}_{2}, 1 \mathrm{NaH}_{2} \mathrm{PO}_{4}, 26 \mathrm{NaHCO}_{3}, 11$ D-glucose, and 0.005 2-chloroadenosine, gassed with $95 \% \mathrm{O}_{2} / 5 \% \mathrm{CO}_{2}$. Whole-cell recording pipettes (3-4 M $\Omega$ ) were filled with a solution containing the following (in mM): $135 \mathrm{CsMeSO}_{3}, 8 \mathrm{NaCl}, 10$ HEPES, 0.25 EGTA, 2 $\mathrm{Mg}_{2} \mathrm{ATP}, 0.3 \mathrm{Na}_{3} \mathrm{GTP}, 0.1$ spermine, 7 phosphocreatine, and 5 QX-314, pH 7.25-7.30 (osmolarity 300 mOsm). Data were collected with a MultiClamp 700B amplifier (Molecular Devices), digitized at $10 \mathrm{kHz}$ using the Digidata 1440A data acquisition system (Molecular Devices), and analyzed offline using pClamp 10 software (RRID:SCR_011323; Molecular Devices).

Experimental design. The AMPA/NMDA ratio was calculated as the peak averaged AMPAR-mediated EPSC at holding potential of $-70 \mathrm{mV}$ divided by the averaged NMDAR-mediated EPSC at holding potential of $+40 \mathrm{mV}$ at a latency at which AMPAR-mediated EPSC responses were fully decayed (50 ms after stimulation). Miniature EPSC (mEPSC) amplitude and frequency were evaluated in $60 \mathrm{~s}$ recordings in the presence of tetrodotoxin $(0.5 \mu \mathrm{M})$ at $-70 \mathrm{mV}$.

We used two different experimental settings to evaluate whether $\mathrm{oA} \beta_{42}$ exerted an extracellular and/or an intracellular effect. To study the extracellular effect, slices were perfused with extracellular 200 pм оA $\beta_{42}$ with one patch pipette filled with vehicle and the other with the $6 \mathrm{E} 10$ antibody that blocks the possible effect due to intracellular oA $\beta_{42}$. To study the intracellular effect, slices were perfused with extracellular vehicle with one patch pipette filled with vehicle and the other with $200 \mathrm{pm}$ $\mathrm{oA} \beta_{42}$. This design also allowed us to concurrently compare the effects of vehicle and $200 \mathrm{pm} \mathrm{oA} \beta_{42}$ injected into adjacent neurons through patch pipettes.

To confirm the ability of $6 \mathrm{E} 10$ to block oA $\beta_{42}$ action, slices were perfused with extracellular $200 \mathrm{pm} \mathrm{oA} \beta_{42}$ paired with $6 \mathrm{E} 10,6 \mathrm{E} 10$ alone, or $200 \mathrm{pm} \mathrm{oA} \beta_{42}$ alone; the patch pipette was filled with vehicle.

\section{Whole-cell LTP recordings in hippocampal brain slices}

Experiments examining LTP were performed from single CA1 pyramidal cells after stimulating the Schaffer collateral fibers by means of a bipolar tungsten electrode (FHC) in acute hippocampal brain slices $(300 \mu \mathrm{m}$ thick) obtained by 21-d-old male C57BL/6 mice, as described previously (Ripoli et al., 2013, 2014). Animals were anesthetized with isoflurane, decapitated, and the brains were rapidly placed in ice-cold cutting solution containing the following (in mM): $124 \mathrm{NaCl}, 3.2 \mathrm{KCl}, 1 \mathrm{NaH}_{2} \mathrm{PO}_{4}, 2$ $\mathrm{MgCl}_{2}, 1 \mathrm{CaCl}_{2}, 26 \mathrm{NaHCO}_{3}, 10$ glucose, $2 \mathrm{Na}$-pyruvate, and 0.6 ascorbic acid, $\mathrm{pH} 7.4,95 \% \mathrm{O}_{2} / 5 \% \mathrm{CO}_{2}$. Slices were sectioned on a vibratome (VT1200S; Leica Microsystems) and rapidly transferred to an incubation chamber filled with ACSF containing the following (in mM): $124 \mathrm{NaCl}$, $3.2 \mathrm{KCl}, 1 \mathrm{NaH}_{2} \mathrm{PO}_{4}, 1 \mathrm{MgCl}_{2}, 2 \mathrm{CaCl}_{2}, 26 \mathrm{NaHCO}_{3}$, and 10 glucose, $\mathrm{pH}$ 7.4 , gassed with $95 \% \mathrm{O}_{2} / 5 \% \mathrm{CO}_{2}$. Slices were allowed to recover at $32^{\circ} \mathrm{C}$ for $1 \mathrm{~h}$ before equilibration at room temperature. During recordings, slices were placed in a recording chamber perfused with heated ACSF $\left(32^{\circ} \mathrm{C}\right)$ and bubbled with $95 \% \mathrm{O}_{2} / 5 \% \mathrm{CO}_{2}$. All recordings were made with the $\mathrm{GABA}_{\mathrm{A}}$ receptor antagonist picrotoxin $(50 \mu \mathrm{M})$ added to the ACSF. Whole-cell recording pipettes (3-5 M $\Omega$ ) were filled with the same internal solution used for dual-patch recordings in organotypic hippocampal slices. Whole-cell recordings were performed with a Multiclamp 700B amplifier (Molecular Devices). A Digidata 1440A series interface and pClamp 10 software were used for data acquisition and stimulation protocols. Data were filtered at $1 \mathrm{kHz}$, digitized at $10 \mathrm{kHz}$, and analyzed online and offline.

Experimental design. To study LTP in CA1 pyramidal cells, the stimulation intensity that elicited one-third of the maximal response amplitude of AMPAR EPSC was used for delivering test pulses every $20 \mathrm{~s}$. CA1 pyramidal cells were held at $-60 \mathrm{mV}$. LTP was induced by two trains of HFS $(100 \mathrm{~Hz}, 1 \mathrm{~s})$ separated by $20 \mathrm{~s}$, with the patched cells depolarized to $0 \mathrm{mV}$. This induction protocol was always applied within 5-7 min of achieving whole-cell configuration, to avoid "washout" of LTP. Responses to test pulse were recorded for $30 \mathrm{~min}$ to assess LTP. The magnitude of LTP was calculated on basis of the averaged EPSC values during the last 5 min of post-HFS recordings (from minute 25 to minute 30 ). LTP magnitude was expressed as the percentage change in the mean EPSC peak amplitude normalized to baseline values, taken as $100 \%$ (i.e., mean values for the $5 \mathrm{~min}$ of recording before HFS).

\section{Electrophysiological field recordings}

Extracellular electrophysiological field recordings were performed on $400 \mu \mathrm{m}$ transverse hippocampal slices as described previously (Puzzo et al., 2008). After a cutting procedure using a manual tissue chopper, slices were transferred to a recording chamber and perfused (1-2 $\mathrm{ml} / \mathrm{min}$ ) with ACSF containing the following (in mM): $124 \mathrm{NaCl}, 4.4 \mathrm{KCl}, 1 \mathrm{Na}_{2} \mathrm{HPO}_{4}$, $25 \mathrm{NaHCO}_{3}, 2 \mathrm{CaCl}_{2}, 2 \mathrm{MgCl}_{2}, 10$ glucose kept at $29^{\circ} \mathrm{C}$ and continuously bubbled with an $\mathrm{O}_{2} / \mathrm{CO}_{2}$ mixture at $95 \%$ and $5 \%$. After 120 min recovery, field EPSPs (fEPSPs) were recorded in CA1 stratum radiatum by a glass electrode filled with ACSF in response to Schaffer collateral stimulation by a bipolar tungsten electrode.

Experimental design. Recordings were performed and analyzed in pClamp 10. We first measured basal synaptic transmission (BST) by stimulating with a series of increasing voltage pulses (from 5 to $35 \mathrm{~V}$ ). This allowed us to preliminarily select healthy slices to be used for electrophysiological recordings. For LTP, baseline was recorded every minute by stimulating at a voltage able to evoke a response of $35 \%$ of the maximum evoked response in BST. After 30-45 min, slices with a stable baseline (slope variation $\pm 5 \%$ ) were used. We recorded for $15 \mathrm{~min}$, and then perfused with vehicle or drugs for the appropriate time. LTP was induced by a theta-burst stimulation (TBS): trains of $10 \times 100 \mathrm{~Hz}$ bursts with five pulses per burst with a $200 \mathrm{~ms}$ interburst interval at the test pulse intensity. To elicit early LTP (E-LTP), we delivered a single TBS train (weak tetanic stimulation), whereas for late LTP (L-LTP, we delivered three TBS trains with a $15 \mathrm{~s}$ intertrain interval (strong tetanic stimulation). Analysis of the fEPSP slope was performed offline and results were expressed by normalizing on the first $15 \mathrm{~min}$ of baseline recordings. In another series of experiments, we evaluated PPF. After BST assessment, slices were perfused with the NMDA receptor antagonist (2R)-amino-5phosphonovaleric acid (APV; $50 \mu \mathrm{M}$ ) for $45 \mathrm{~min}$, and then treated with vehicle or drugs in APV for the appropriate time. Two paired pulses within a time interval of 10,20,30,40,50,100, 200, 500, and $1000 \mathrm{~ms}$ were delivered. PPF was measured as percentage of the synaptic response of the second against the first delivered stimulus.

\section{Intrahippocampal injections of $o A \beta_{42}$}

Mice underwent stereotaxic surgery for cannulas implantation. After anesthesia with tiletamine + zolazepam $(60 \mathrm{mg} / \mathrm{kg})$ and medetomidine (40 $\mu \mathrm{g} / \mathrm{kg}$ ), mice were implanted with a 26-gauge guide cannula into the dorsal part of the hippocampi (coordinates from bregma: posterior $=$ $2.46 \mathrm{~mm}$, lateral $=1.50 \mathrm{~mm}$ to a depth of $1.30 \mathrm{~mm}$ ). The cannulas were fixed to the skull with acrylic dental cement (RelyX ${ }^{\mathrm{TM}}$ Unicem, $\left.3 \mathrm{M}\right)$ and mice were allowed to recover for a minimum of $6-8 \mathrm{~d}$. Twenty minutes before the training phase (T1), mice were bilaterally infused with $\mathrm{oA} \beta_{42}$ 
solution or vehicle or oA $\beta_{42}+\mathrm{Rp}-8$-Br-cGMPS in a final volume of $1 \mu \mathrm{l}$ over $1 \mathrm{~min}$ with a microsyringe connected to the cannulas via polyethylene tubing. During infusion, animals were handled gently to minimize stress. After infusion, the needle was left in place for another minute to allow diffusion. In some animals, after behavioral studies, a solution of $4 \%$ methylene blue was infused for localization of infusion cannulas.

\section{Novel object recognition (NOR) test}

The NOR test was performed as described previously (Bollen et al., 2014; Palmeri et al., 2017) in sex-balanced WT mice. Mice underwent $3 \mathrm{~d}$ of habituation to the arena, objects, and intrahippocampal injections; $1 \mathrm{~d}$ of training (T1); and $1 \mathrm{~d}$ of testing (T2). The arena was a plastic white box $(50 \times 35 \times 45 \mathrm{~cm})$, and objects (e.g., pyramid, cube, truncated sphere, etc.) were designed by a computer-aided design software (Solidworks) and printed in polylactic acid with a Prusa-inspired 3D printer of our design. After each trial, the box and the objects were cleaned with $70 \%$ ethanol and dried with absorbent paper.

Experimental design. During the first day of habituation the mouse was put into the empty arena and allowed to explore it for $5 \mathrm{~min}$. During the second and the third day (familiarization with objects), the mouse was put into the arena containing two different objects, randomly chosen among our object collection and changed from day to day, for $5 \mathrm{~min}$. During the fourth day, NOR training session (T1) was performed with two different protocols: short T1 and long T1. The mouse was put into the arena and allowed to explore two identical objects placed in the central part of the box, equally distant from the perimeter and the center, for $3 \mathrm{~min}$ (short T1) or $10 \mathrm{~min}$ (long T1). During the fifth day, the mouse underwent the second trial (T2) to test memory retention for $10 \mathrm{~min}$. The long delay interval of $24 \mathrm{~h}$ between T1 and T2 did not allow storage of memory information (natural forgetting) in mice that were previously exposed to a short T1 (no discrimination between the familiar and the novel objects). Conversely, long-term memory (LTM) could be formed in mice that were previously exposed to a long T1. In T2, mice were presented with two different objects, respectively a "familiar" (i.e., the one used for T1) and a "novel" object. Animal exploration was defined as the mouse pointing its nose toward the object from a distance not $>2 \mathrm{~cm}$ and was measured in T2 to analyze: (1) the discrimination index, exploration of novel object minus exploration of familiar object/total exploration time, and (2) total exploration time, the time spent exploring the objects was scored using a personal computer by an experimenter who was blinded to the conditions tested. We excluded from the analyses mice with a total exploration time $<5 \mathrm{~s}$.

\section{Electron microscopy of hippocampal slices}

Hippocampal slices ( $n=2$ for each conditions from 8 animals) were quickly immersed (within $\sim 30 \mathrm{~s}$ after $120 \mathrm{~min}$ of electrophysiological recording) in a solution containing $4 \%$ paraformaldehyde and $0.5 \%$ glutaraldehyde in phosphate buffer (PB) and then stored for 6 weeks in the same fixative solution at $4^{\circ} \mathrm{C}$. Subsequently, slices were exposed to an embedding procedure as described previously (Melone et al., 2011, 2015). Briefly, they were postfixed in $1 \%$ osmium tetroxide in PB for 45 min and contrasted with $1 \%$ uranyl acetate in maleate buffer, $\mathrm{pH} 6.0$, for $1 \mathrm{~h}$. Dehydrated sections were immersed in propylene oxide, infiltrated with a mixture of Epon/Spurr resins (Electron Microscopy Sciences) sandwiched between Aclar films and polymerized at $60^{\circ} \mathrm{C}$ for $48 \mathrm{~h}$. A small block of tissue containing CA1 stratum radiatum was selected by light microscopic inspection, glued to blank epoxy, and sectioned with an ultramicrotome (MTX; Research and Manufacturing Company). Ultrathin sections $(\sim 60 \mathrm{~nm}$; for a total of $20-25$ ultrathin sections for each small selected block) were mounted on 200 mesh copper grids, stained with Sato's lead, and examined with Philips EM 208 and/or CM10 electron microscopes coupled to a MegaView-II high resolution CCD camera (Soft Imaging System).

Experimental design. Electron microscopy was performed on hippocampal slices treated with vehicle, vehicle $+1 \mathrm{TBS}, \mathrm{oA} \beta_{42} 200 \mathrm{pM}$, or $\mathrm{A} \beta 200 \mathrm{pm}+1$ TBS. These slices were randomly collected during electrophysiological field recording experiments $120 \mathrm{~min}$ after tetanic stimulation and analysis of recordings was performed for each sample following the sample protocol described above. Quantitative analysis of vesicle pool, number of docked vesicles, area of spines, length of the postsynaptic density (PSD), and of the proportion of perforated synapses (Shepherd and Harris, 1998; Pozzo-Miller et al., 1999; Geinisman, 2000; Bourne et al., 2013; Babits et al., 2016) was performed. Randomly selected electron microscopical fields of the stratum radiatum (vehicle, $n=$ 87 ; vehicle +1 TBS, $n=116$; oA $\beta 42200$ pм, $n=92$; oA $\beta 42200$ pм +1 TBS, $n=113$ ) with at least one identifiable axospinous synapse (Shepherd and Harris, 1998) were acquired at original magnification of $36,000 \times$.

Axospinous synapses were identified by the presence of a presynaptic terminal with vesicles, including those nearby the presynaptic density (i.e., the active zone), a synaptic cleft displaying electrodense material, and a postsynaptic membrane associated with a prominent PSD within the postsynaptic spines (Peters et al., 1991; DeFelipe et al., 1999). The distinction between vesicle pools (which comprise the reserve vesicle pool) and docked vesicles (which are thought to be part of the readily releasable pool), was made according to Shepherd and Harris 1998; Pozzo-Miller et al., 1999; Bourne et al., 2013. Briefly, vesicle pools were determined by counting the total number of small vesicles $(\sim 50 \mathrm{~nm})$ per terminal; the docked vesicles pool by counting the vesicles touching the membrane of the presynaptic active zone. Spines profile area and PSD length were measured by ImageJ software tools (Schneider et al., 2012; Babits et al., 2016). Spine profiles and PSD were traced along the membranes and measured; PSD length corresponded to the distance between the edges of PSD. Perforated synapses were identified based on the presence of a discontinuous PSD (Geinisman, 2000; Babits et al., 2016). Ultrathin sections and microscopical features of axospinous synapses were examined and analyzed in a blinded manner.

\section{Western blot on hippocampal slices}

Western blot (WB) analysis was performed as described previously (Caraci et al., 2015). Tissues were homogenized in RIPA buffer (Thermo Fisher Scientific) in the presence of phosphatase and protease inhibitors (Thermo Fisher Scientific), and sonicated 3 times for $10 \mathrm{~min}$. Protein concentrations were determined by Pierce BCA protein assay kit (Thermo Fisher Scientific) and equal amounts of proteins $(30-50 \mu \mathrm{g}$ ) were then loaded onto $10 \%$ or $12 \%$ Tris-glycine polyacrylamide gels for electrophoretic separation. Membranes were blocked for $1 \mathrm{~h}$, at room temperature, in a solution of 5\% nonfat dry milk in Tris-buffered saline containing $0.1 \%$ Tween 20 or SEAblock (Thermo Fisher Scientific) before incubation overnight at $4^{\circ} \mathrm{C}$ with the following primary antibodies: mouse anti-neuronal nitric oxide synthase (anti-nNOS) (Thermo Fisher Scientific, catalog \#37-2800, RRID:AB_2533308; 1:1000); rabbit anti-pCREB (ser133) (Millipore, catalog \#06-519, RRID:AB_310153; 1:1000); mouse anti-CREB (Cell Signaling Technology, catalog \#9104, RRID: AB_490881; 1:500); rabbit anti-p-CaMKII (thr286) (Cell Signaling Technology, catalog \#12716, RRID:AB_2713889; 1:1000); mouse antiCaMKII $\alpha$ (Cell Signaling Technology, catalog \#50049, RRID: AB_2721906; 1:1000); rabbit anti-BDNF (Millipore, catalog \#AB1534, RRID:AB_90746; 1:500). Mouse anti tubulin (Sigma Aldrich, catalog \#T5293, RRID:AB_477580; 1:1000) was used as loading control. Molecular weights for immunoblot analysis were determined using precision Plus Protein Dual color Standards (Bio-Rad), PAGE-MASTER Protein Standard (Genscript). Protein detection was performed by using a secondary infrared fluorescent dye conjugated antibody absorbing at 800 or $680 \mathrm{~nm}$. The secondary antibody goat anti-rabbit IRDye 680 (Li-Cor Biosciences, catalog \#926-68021, RRID:AB_10706309) and goat antimouse IRDye 800CW (Li-Cor Biosciences, catalog \#926-32210, RRID: AB_621842) were used at 1:20,000 and 1:30,000, respectively. Blots were visualized using an Odyssey Infrared Imaging Scanner (Li-Cor). In other experiments, after incubation with appropriate secondary horseradish peroxidase-conjugated antibodies (1:2500; Cell Signaling Technology), visualization was performed with ECL plus (GE Healthcare) using UVItec (Cambrige Alliance). Densitometric analysis was performed with either Odyssey Infrared Imaging Scanner or UVItec or ImageJ software after normalization with loading controls.

Experimental design. We collected slices from electrophysiological field recordings experiments $120 \mathrm{~min}$ after tetanic stimulation. For each experimental condition (vehicle, 1 TBS, $\mathrm{A} \beta, \mathrm{A} \beta+1$ TBS; or vehicle, 3 TBS 
for nNOS), 4 slices from different animals were collected to obtain a sample; 2-3 samples for a total of 8-12 slices were used to evaluate the expression of each protein of interest.

\section{Statistical analyses}

For each experiment, sample size relied on power analyses $(\alpha=0.05$, power $1-\beta=0.80$ ) calculated by G-Power 3.1 software suggesting for each condition a minimum of 6 slices (electrophysiology) and 8 mice (behavioral studies) to obtain an effect size $=0.62$. Experimenters were blinded to treatment. All data are expressed as mean \pm SEM.

After data collection, statistical analysis was performed by SigmaPlot 12.0 (RRID:SCR_003210), Systat 9 (RRID:SCR_010455) and GraphPad Prism 7 (RRID:SCR_002798) software. A preliminary analysis of normal distribution was performed by Shapiro-Wilk normality test. We also used the following tests: (1) ANOVA for repeated measures to analyze PPF and LTP (120 min after tetanus) curves; (2) one-way ANOVA with Bonferroni's or Tukey's post hoc correction for LTP graphs displaying residual potentiation (average of the last $5 \mathrm{~min}$ of LTP recording) for analyses of discrimination index and total exploration time among conditions in NOR and for WB; (3) two-samples $t$ test to compare conditions in dual-patch recording; and (4) one-sample $t$ test to compare discrimination index with zero. Given the non-normal distribution of electron microscopical data, as assessed by D'Agostino and Pearson normality test, comparison of the number of pool vesicles, docked vesicles, area of spines, and PSD length between all groups was made by nonparametric Kruskal-Wallis test with Dunn's multiple-comparisons test. The percentages of nonperforated and perforated synapses were compared using nonparametric contingency analysis with Fisher's test. The level of significance was set at $p<0.05$.

\section{Results}

\section{Picomolar concentrations of extracellular oA $\boldsymbol{\beta}_{42}$ affect} spontaneous neurotransmitter release and synaptic plasticity Intraneuronal uptake and accumulation of high doses of oA $\beta_{42}$ are key events leading to impairment of synaptic transmission, LTP, and memory (Ripoli et al., 2014; Puzzo et al., 2017). However, it is not known whether the capability of oA $\beta_{42}$ to enhance synaptic function when at low concentrations is triggered by an extracellular mechanism or if it requires protein internalization.

To address this issue, we first characterized our oA $\beta_{42}$ preparations and confirmed that they contained both monomers and oligomers (Fig. 1A), as recently shown (Gulisano et al., 2018b). DR curves obtained by treating hippocampal slices with different doses of oA $\beta_{42}$ (from 2 pM to $200 \mathrm{nM}$ ) for 20 min before tetanus confirmed that $200 \mathrm{pM} \mathrm{oA} \beta_{42}$ was the concentration inducing the maximum enhancement of LTP (Fig. $1 B$ ), consistent with our previous findings (Puzzo et al., 2008, 2012).

Next, we studied the effect of extracellular and intracellular $200 \mathrm{pm} \mathrm{oA} \beta_{42}$ on glutamatergic basal synaptic transmission through dual patch-clamp whole-cell recordings of adjacent CA1 pyramidal neurons of organotypic slice cultures in the following experimental conditions: (1) extracellular $200 \mathrm{pM} \mathrm{oA} \beta_{42}$, with one patch pipette filled with vehicle and the other with an antibody raised against human $\mathrm{A} \beta 42$ (6E10) and (2) extracellular vehicle with one patch pipette filled with vehicle and the other with $200 \mathrm{pm} \mathrm{oA} \beta_{42}$ (Fig. 1C). We found no effect of oA $\beta_{42}$ onto AMPA and NMDA glutamatergic receptor evoked currents when the peptide was administered either extracellularly or intracellularly (Fig. $1 D, E$ ). Conversely, extracellular administration of $\mathrm{oA} \beta_{42}$ increased the spontaneous release of neurotransmitter from the presynaptic terminal measured through the mEPSC frequency without altering their amplitude $20 \mathrm{~min}$ after its application (Fig. $1 F, G$ ). Remarkably, intracellular application of 6E10 did not block the effect of extracellular oA $\beta_{42}$, confirming that the $\mathrm{oA} \beta_{42}$-induced modification of glutamatergic transmission does not require peptide internalization. Control experiments confirmed that blocking oA $\beta_{42}$ with extracellular $6 \mathrm{E} 10$ prevented $\mathrm{oA} \beta_{42}$ to increase mEPSC frequency (Fig. $1 \mathrm{H}$ ), whereas $6 \mathrm{E} 10 \mathrm{did}$ not affect mEPSC per se.

Further experiments in which LTP was studied through patch-clamp technique showed that $200 \mathrm{pm} \mathrm{oA} \beta_{42}$ increased EPSC amplitude recorded for $30 \mathrm{~min}$ after a high-frequency stimulation ( 2 trains at $100 \mathrm{~Hz}$ for $1 \mathrm{~s}$ separated by $20 \mathrm{~s}$ ) only when extracellularly applied, not when injected into CA1 pyramidal neurons through the patch pipette (Fig. 1I). These findings demonstrate that picomolar concentrations of oA $\beta_{42}$ extracellularly modulate glutamatergic transmission and plasticity and it they do act through a direct intracellular mechanism.

\section{Picomolar concentrations of $\mathrm{oA} \boldsymbol{\beta}_{42}$ affect PPF and convert E-LTP into L-LTP and short-term memory (STM) into LTM}

The increase of mEPSC frequency prompted us to investigate whether oA $\beta_{42}$ affects PPF, a presynaptic form of short-term plasticity linked with changes in release probability (Zucker and Regehr, 2002). We found that 20 min perfusion with $200 \mathrm{pm}$ $\mathrm{oA} \beta_{42}$ decreased PPF (Fig. $2 A$ ), thus suggesting an increase of the release probability (Dobrunz and Stevens, 1997). A DR curve confirmed that $200 \mathrm{pm}$ was the dose capable of affecting PPF (Fig. $2 B)$. To further investigate the role of $A \beta$ in PPF, we suppressed endogenous $A \beta$ through the anti-A $\beta$ antibody M3.2, specifically targeting murine $\mathrm{A} \beta$. This induced the opposite effect, an enhancement of PPF, which was rescued by concomitant perfusion with human $200 \mathrm{pM} \mathrm{oA} \beta_{42}$ (Fig. 2C), not recognized by M3.2. These findings are consistent with a positive modulatory role of $\mathrm{A} \beta$ onto neurotransmitter release probability.

Next, we investigated whether $200 \mathrm{pm} \mathrm{oA} \beta_{42}$ influenced the E-LTP, a form of protein-synthesis-independent plasticity that involves a change in presynaptic neurotransmitter release and short-term kinase activity (Huang, 1998). We found that pretreatment with $200 \mathrm{pM} \mathrm{oA} \beta_{42}$ converted E-LTP obtained through a weak tetanic stimulation (1 TBS) into L-LTP (Fig. $2 D$ ). The potentiation induced by pairing $200 \mathrm{pM} \mathrm{oA} \beta_{42}$ with 1 TBS was comparable to that induced by a strong tetanic stimulation consisting of 3 TBSs elicited with a 15 s intertrain interval. To confirm that $200 \mathrm{pM} \mathrm{oA} \beta_{42}$ converted E-LTP into the traditional proteinsynthesis-dependent L-LTP (Johnstone and Raymond, 2011), slices were continuously perfused with the translation inhibitor ANI (20 $\mu \mathrm{M} ; 30 \mathrm{~min}$ before and 25 after tetanus), which prevented the oA $\beta_{42}$-induced L-LTP (Fig. 2E). Additionally, we confirmed that ANI perfusion inhibits 3-TBS-induced L-LTP without affecting 1-TBS-induced E-LTP (Fig. 2E), as the latter is known to not involve new protein synthesis (Johnstone and Raymond, 2011). These observations support a role for oA $\beta_{42}$ in triggering new protein synthesis and gene transcription.

Because LTP represents the cellular surrogate of memory, we assessed whether bilateral intrahippocampal injections with 200 pM оA $\beta_{42} 20$ min before training were able to convert STM into LTM. To this end, we used an NOR protocol in which the short time exposure ( $3 \mathrm{~min}$ ) during the training phase (T1) does not allow animals to discriminate between the old and the new object after a $24 \mathrm{~h}$ long-term interval due to natural forgetting (Bollen et al., 2014; Palmeri et al., 2017). The analyses of the discrimination index indicated that mice receiving a weak stimulus (i.e., short exposure in T1) paired with $200 \mathrm{pM} \mathrm{oA} \beta_{42}$ were able to discriminate between the old and the familiar object after $24 \mathrm{~h}$ compared with vehicle-treated animals showing natural forgetting. This $\mathrm{oA} \beta_{42}$-induced LTM was comparable to that induced by a stronger training stimulus (10 min of exposure in T1) (Fig. 2F). Total 
A

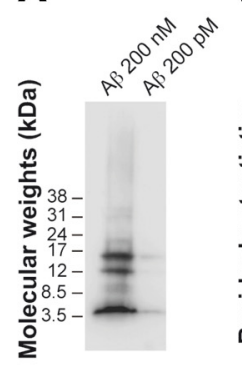

B

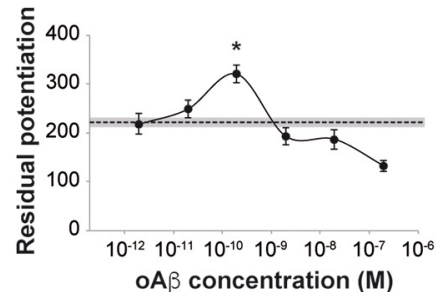

F

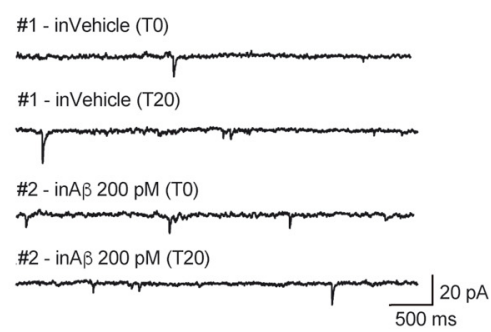

C

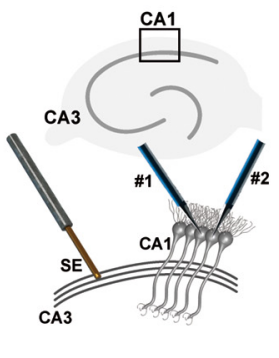

D

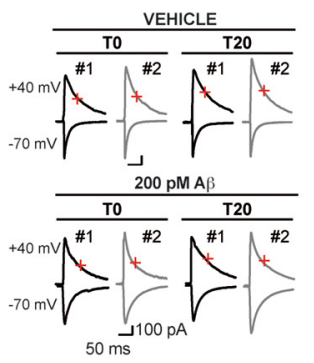

E

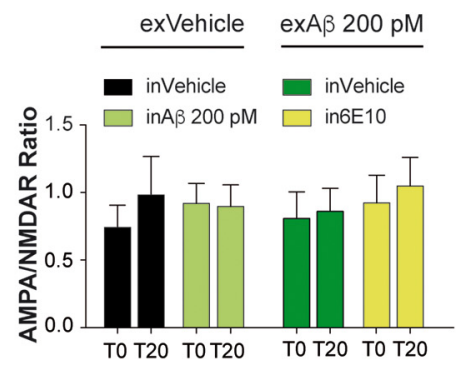

G

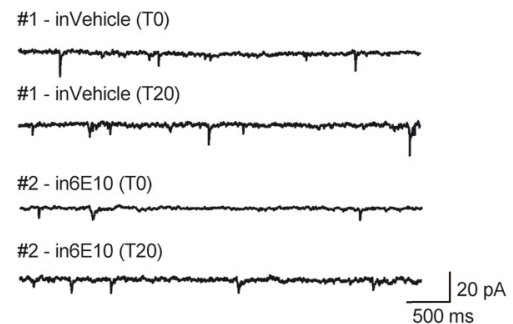

H

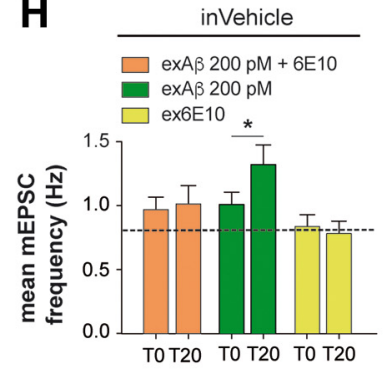

I

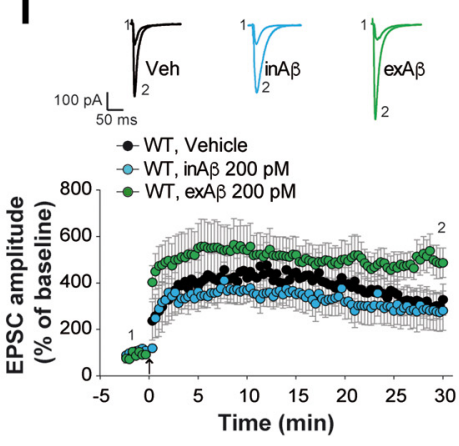

Figure 1. Extracellular, but not intracellular, picomolar concentrations of $0 \mathrm{~A} \beta_{42}$ affect spontaneous release of neurotransmitter and synaptic plasticity. $A$, Characterization of synthetic human ${ }_{0} \mathrm{~A} \beta_{42}$ solutions by WB analysis showing the presence of monomers, dimers, trimers, and tetramers for $200 \mathrm{~nm} \mathrm{OA} \beta_{42}$ solution and the presence of monomers and tetramers for $200 \mathrm{pm} 0 \mathrm{~A} \beta_{42}$. $\boldsymbol{B}$, DR curve for the effect of $\mathrm{OA} \beta_{42}$ (from $2 \mathrm{pm}$ to $200 \mathrm{~nm}, n=5$ for each concentration) on CA1-LTP indicates that the peptide has a maximum stimulatory effect at $200 \mathrm{pm}(321.04 \pm 17.92 \%$ of baseline vs $228.63 \pm 20.29 \%$ of baseline; $F_{(6,28)}=9.882, p<0.0001$; Bonferroni's $\left.p=0.031\right)$ and an inhibitory effect at $200 \mathrm{~nm}(133.25 \pm 11.59 \%$ of baseline; Bonferroni's $p=0.023)$. The dotted horizontal line corresponds to treatment with vehicle. The residual potentiation was calculated by averaging the last 5 min of LTP. C, Schematic representation of dual whole-cell recordings from adjacent (\#1 and \#2) CA1 hippocampal pyramidal neurons (see Materials and Methods for details). D, Representative AMPAR- and NMDAR-EPSCs at time 0 (T0) and 20 min after extracellular application of vehicle or $200 \mathrm{pm} \mathrm{OA} \beta_{42}$ (T20). The amplitude of NMDA currents recorded at $+40 \mathrm{mV}$ (holding potential) was measured at 50 ms poststimulus (red crosses). $\boldsymbol{E}$, Neither intraneuronal (in) nor extracellular (ex) $200 \mathrm{pm} 0 \mathrm{~A} \beta_{42}$ affected AMPAR/NMDAR ratios. Slices perfused with exVehicle: inVehicle T0 $=0.74 \pm 0.16, \mathrm{~T} 20=0.97 \pm 0.28, n=10$; in $200 \mathrm{pm} 0 \mathrm{~A} \beta_{42} \mathrm{~T} 0=0.92 \pm$ $0.14, \mathrm{~T} 20=0.90 \pm 0.16, n=10$. Slices perfused with ex $200 \mathrm{pm} 0 \mathrm{AA} \beta_{42}$ : inVehicle T0 $=0.80 \pm 0.19, \mathrm{~T} 20=0.86 \pm 0.16, n=15$; in6E10 T0 $=0.92 \pm 0.20$, T20 $=1.04 \pm 0.21, n=15 . \boldsymbol{F}$, Representative $\mathrm{mEPSC}$ traces recorded in neurons treated with vehicle and $200 \mathrm{pm} \mathrm{inA} \beta_{42}$ at T0 and T20. Intraneuronal $200 \mathrm{pm} 0 \mathrm{~A} \beta_{42}$ had no significant effect on mEPSC frequency (from $0.82 \pm 0.18$ $\mathrm{Hz}$ at T0 to $0.63 \pm 0.10 \mathrm{~Hz}$ at T20,n=14; $p=0.10$ ) or amplitude (from $11.33 \pm 2.58 \mathrm{pA}$ at T0 to $8.64 \pm 2.06 \mathrm{pA}$ at T20, $n=14 ; p=0.07$ ) compared with slices in which cells were injected with vehicle and extracellularly perfused with vehicle (mEPSC frequencies from $0.87 \pm 0.13 \mathrm{~Hz}$ at T0 to $0.78 \pm 0.10 \mathrm{~Hz}$ at T20, $n=14 ; p=0.07 ; \mathrm{mEPSC}$ amplitudes from $13.58 \pm 2.77 \mathrm{pA}$ at T0 to $10.73 \pm 2.97 \mathrm{pA}$ at T20, $n=14 ; p=0.19$ ). $G$, Extracellular application of $200 \mathrm{pm} \mathrm{OA} \beta_{42}$ significantly increased $\mathrm{mEPSC}$ frequency both in vehicle-injected neurons (from $0.79 \pm 0.08 \mathrm{~Hz}$ at T0 to $1.10 \pm 0.10 \mathrm{~Hz}$ at T20, $n=14 ; p=0.002$ ) and adjacent 6E10-injected neurons (from $0.85 \pm 0.11 \mathrm{~Hz}$ at T0 to $1.18 \pm 0.15 \mathrm{~Hz}$ at T20, $n=14 ; p=0.0008$ ) without altering the mEPSC amplitude (mean amplitude) of: (1) vehicle: T0 $=10.6 \pm 1.9 \mathrm{pA}, \mathrm{T} 20=12.2 \pm 1.6 \mathrm{pA}, n=14 ; p=0.20$ or (2i) $6 \mathrm{E} 10: \mathrm{T} 0=9.7 \pm 1.4 \mathrm{pA}, \mathrm{T} 20=11.2 \pm 2.7 \mathrm{pA}, n=14 ; p=0.51$. $\boldsymbol{H}$, Extracellular application of $200 \mathrm{pm} 0 \mathrm{~A} \beta_{42}$ paired with $6 \mathrm{E} 10$ or $6 \mathrm{E} 10$ alone did not modify mEPSC frequency in vehicle-injected neurons (exA $\beta+6 \mathrm{E} 10$ : from $0.96 \pm 0.08 \mathrm{~Hz}$ at T0 to $1.00 \pm 0.15 \mathrm{~Hz}$ at T20, $n=18 ; p=0.746$; 6E10: from $0.83 \pm 0.07 \mathrm{~Hz}$ at T0 to $0.77 \pm 0.10 \mathrm{~Hz}$ at T20,n=10; $=0.543$ ). In interleaved experiments, extracellular $200 \mathrm{pm} 0 \mathrm{~A} \beta_{42}$ was still capable of incresing the mEPSC frequency (from $1.00 \pm 0.10 \mathrm{~Hz}$ at T0 to $1.31 \pm 0.15 \mathrm{~Hz}$ at T20, $n=8 ; p=0.029) . I$, Extracellular $0 \mathrm{~A} \beta_{42}(n=11)$ enhanced LTP elicited through a high-frequency stimulation (two trains at $100 \mathrm{~Hz}$ for $1 \mathrm{~s} s e p a r a t e d$ by 20 s) compared with vehicle $(n=10)$ (Bonferroni's $p=0.003$ ). By contrast, intracellular $0 A \beta_{42}$ did not modify potentiation (Bonferroni's $\left.p>0.05\right)$. ANOVA among all: $F_{(2,28)}=10.846 ; p=$ $0.001{ }^{* *} p<0.005 ;{ }^{* * *} p<0.001$. Data are expressed as mean \pm SEM.

exploration time was similar in all groups (Fig. 2F). Thus, 200 pM $\mathrm{oA} \beta_{42}$ converts STM into LTM.

Picomolar concentrations of $\mathrm{oA} \boldsymbol{\beta}_{42}$ induce ultrastructural changes of hippocampal CA1 synapses at both presynaptic and postsynaptic levels

Synaptic plasticity is accompanied by structural changes occurring at both the presynaptic and postsynaptic levels (Bourne et al., 2013). We therefore investigated whether $\mathrm{oA} \beta_{42}$ determines spe- cific ultrastructural changes (i.e., vesicle pool, number of docked vesicles, area of spines, PSD length, and percentage of perforated synapses; Table 1) at axospinous synapses of the CA1 stratum radiatum in slices used for electrophysiological experiments collected and stored at 120 min after $\mathrm{A} \beta$ treatment. Quantitative electron microscopy showed an increase of docked vesicles in axon terminals from slices treated with $200 \mathrm{pM} \mathrm{oA} \beta_{42}$ and of PSD length in spines from slices treated with $\mathrm{oA} \beta_{42}$ paired with a weak stimulation (Fig. 3). Together, these ultrastructural changes 
A

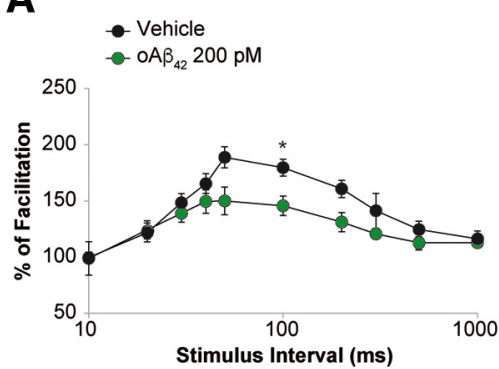

D

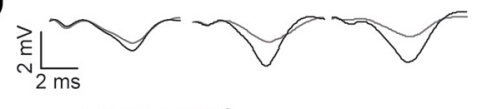

- Vehicle, 1 TBS

- Vehicle, 3 TBS

$0 \mathrm{~A} \beta_{42} 200 \mathrm{pM}, 1$ TBS

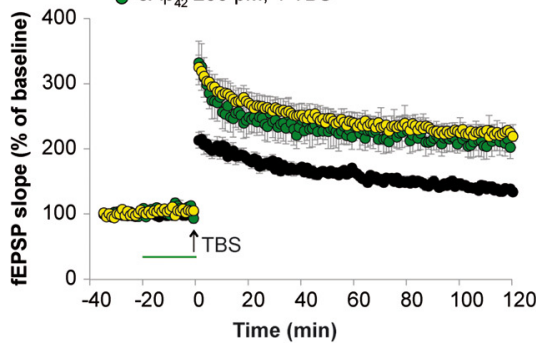

B

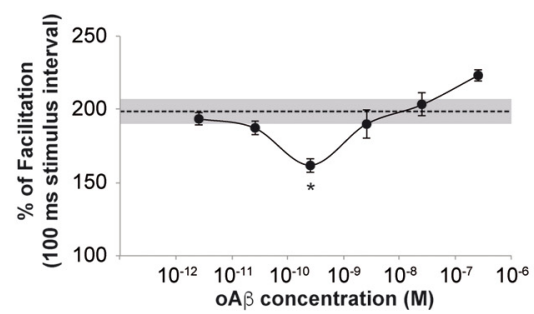

E

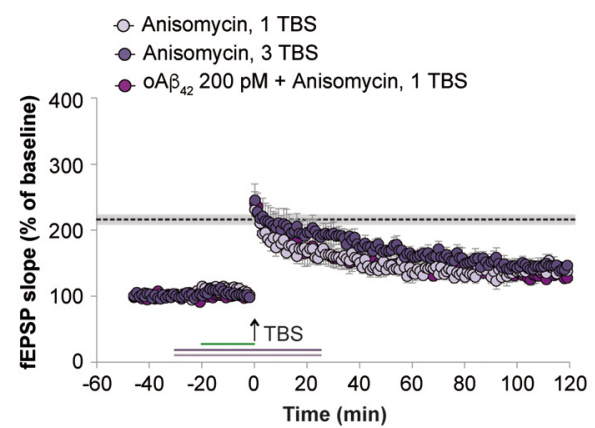

C

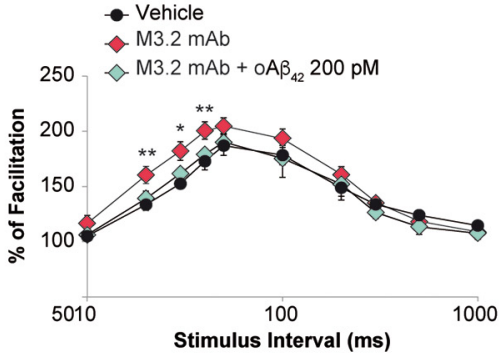

$\mathbf{F}$

- Vehicle, short T1

- Vehicle, long T1

- $\mathrm{OA} \beta_{42} 200 \mathrm{pM}$, short T1
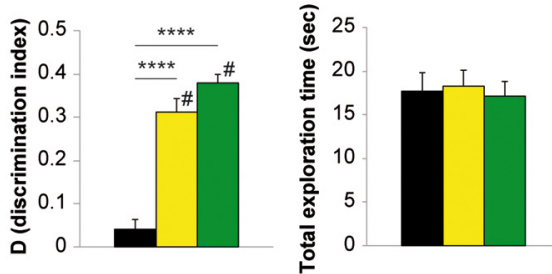

Figure 2. Picomolar concentrations of $0 \mathrm{~A} \beta_{42}$ decrease PPF and convert E-LTP into L-LTP, as well as STM into LTM. $A$, PPF was decreased in slices perfused with 200 pM $0 \mathrm{~A} \beta_{42}$ for 20 min compared with control slices (facilitation at $100 \mathrm{~ms}$ interval here and in following panels: vehicle $=179.58 \pm 7.47 \%, n=9 ; 200 \mathrm{pm} 0 \mathrm{~A} \beta_{42}=145.67 \pm 8.74 \%, n=10 ; \mathrm{ANOVA}$ for repeated measures for the entire curve $F_{(1,17)}=6.262, p=0.023$; Bonferroni's $p=0.041$ at $100 \mathrm{~ms}$. $\boldsymbol{B}, \mathrm{DR}$ curve for the effect of $0 \mathrm{~A} \beta_{42}$ (from 2 pm to $200 \mathrm{~nm}, n=7$ for each concentration) on PPF indicates that the peptide has a maximum stimulatory effect at $200 \mathrm{pm}$. Curve showing the percentage of facilitation at $100 \mathrm{~ms}$ stimulus interval (Bonferroni's $p=$ 0.022 between vehicle and 200 pм $0 A \beta_{42}$ ). The dotted horizontal line corresponds to treatment with vehicle. $C$, Increase of PPF caused by the anti-murine $A \beta$ antibody M3.2 mAb $\left(193.75 \pm 8.43 \%, n=11 ; F_{(1,18)}=4.749, p=0.043\right.$ vs vehicle; Bonferroni's $p=0.007,0.011$ and 0.006 at 20,30 and 40 ms) was rescued by 200 pм human oA $\beta_{42}$ ( $175.39 \pm 17.22 \%$, $n=10 ; F_{(1,19)}=5.111, p=0.036$ vs M3.2 mAb; $F_{(1,17)}=0.006, p=0.939$ vs vehicle). $D$, Twenty-minute perfusion with $200 \mathrm{pm} 0 \mathrm{~A} \beta_{42}$ converted E-LTP elicited through a weak tetanic stimulation (1 TBS) to L-LTP (134.24 $\pm 5.44 \%$ of baseline vs $220.10 \pm 17.74 \%$ of baseline, $\left.n=7 / 7 ; F_{(1,12)}=9.883, p=0.008\right)$, inducing a potentiation similar to that obtained with a strong tetanic stimulation (3 TBS) (219.91 $\pm 7.75 \%$ of baseline, $n=7 ; F_{(1,12)}=0.321, p=0.582$ comparing 0 A $\beta_{42}+1$ TBS vs vehicle +3 TBS). $\boldsymbol{E}$, Perfusion ( 30 min before and 25 min after tetanus) with the translation inhibitor ANI blocked the $0 \mathrm{~A} \beta_{42}$-induced L-LTP $\left(127.48 \pm 8.71 \%\right.$ of baseline, $n=7 ; F_{(1,12)}=11.946, p=0.005$ vs $0 \mathrm{~A} \beta_{42}+1$ TBS). ANI did not modify E-LTP induced by 1 TBS ( $137.92 \pm 8.05 \%$ of baseline, $n=7 ; F_{(1,11)}=3.091 ; p=0.106$ vs vehicle +1 TBS) but blocked L-LTP induced by 3 TBS ( $146.41 \pm 14.77 \%$ of baseline, $n=6 ; F_{(1,12)}=25.976, p<0.0001$ vs vehicle +3 TBS). Shaded area with dashed line corresponds to mean + SEM of the 5 last recorded point in slices treated with vehicle +3 TBS as in $\boldsymbol{D}$. $\boldsymbol{F}$, Evaluation of recognition memory indicated a difference in discrimination index ( $D$; the exploration of novel object minus exploration of familiar object/total exploration time) between vehicle-treated mice that underwent a 3 min exposition in T1 (short T1) or a 10 min exposition in T1 (long T1) ( $0.04 \pm 0.02$ vs $0.31 \pm 0.03$ comparing short T1 vs long T1, $n=$ $10 / 10$ sex-balanced mice; Bonferroni's $p<0.0001)$. Comparison of $D$ with zero confirmed that a long T1 was able to induce LTM in a $24-h$-delay novel object recognition task $\left(t_{(9)}=\right.$ $9.604, p<0.0001)$, whereas a short T1 did not $\left(t_{(9)}=1.62, p=0.140\right)$. Intrahippocampal injections with 200 pM oA $\beta_{42} 20$ min before a short T1 converted STM into LTM $(D=0.38 \pm$ $0.01, n=10$ sex-balanced mice; $t_{(9)}=19.79, p<0.0001$ comparing $D$ with zero in $0 A \beta_{42}+$ Short T1). One-way ANOVA with Bonferroni's post hoc corrections confirmed the significant difference between $D$ in vehicle- and $0 A \beta_{42}$-treated mice previously exposed to a short T1 ( $\left.p<0.0001\right)$. The increase of $D$ induced by treatment with $0 A \beta_{42}$ was similar to that obtained in vehicle-treated mice that spent a longer period in $\mathrm{T} 1$ ( $p=0.314$ comparing $\mathrm{D}$ in $0 \mathrm{~A} \beta_{42}+$ short T1 vs vehicle + long T1). Right, Total exploration time was comparable in the 3 groups of mice $\left(F_{(2,27)}=0.086, p=0.918\right)$. ${ }^{*} p<0.05,{ }^{* *} p<0.01,{ }^{* * *} p<0.0001$; \# difference from 0 . Data are expressed as mean \pm SEM.

Table 1. Detailed results of TEM performed on hippocampal slices stored at $120 \mathrm{~min}$ after electrophysiological recordings in the following experimental conditions: vehicle (V), vehicle +1 TBS tetanus $(V+T), 0 A \beta_{42} 200$ pM $(A \beta), 0 A \beta_{42} 200$ pM +1 TBS tetanus $(A \beta+T)$

\begin{tabular}{|c|c|c|c|c|c|c|c|c|c|c|}
\hline $\begin{array}{l}\text { Experimental } \\
\text { condition }\end{array}$ & V & $V+T$ & $A \beta$ & $A \beta+T$ & Statistical a & talyses ${ }^{a}(p$ v & alue) & & & \\
\hline \multicolumn{11}{|l|}{ Asymmetric } \\
\hline synapses (n) & $n=172$ & $n=151$ & $n=124$ & $n=113$ & Vvs V $+T$ & Vvs $A \beta$ & Vvs $A \beta+T$ & $V+T$ vs $A \beta$ & $A \beta$ vs $A \beta+T$ & $V+T$ vs $A \beta+T$ \\
\hline Vesicle pool (n) & $74.8 \pm 2.4$ & $70.2 \pm 2.9$ & $72.9 \pm 3.1$ & $77.3 \pm 3.0$ & 0.48 & $>0.99$ & $>0.99$ & $>0.99$ & $>0.99$ & 0.73 \\
\hline Docked vesicles (n) & $1.7 \pm 0.08$ & $3.7 \pm 0.12$ & $2.6 \pm 0.10$ & $4.2 \pm 0.14$ & $<0.0001$ & $<0.0001$ & $<0.0001$ & $<0.0001$ & $<0.0001$ & 0.13 \\
\hline Area of spines $\left(\mu \mathrm{m}^{2}\right)$ & $0.09 \pm 0.004$ & $0.11 \pm 0.006$ & $0.10 \pm 0.005$ & $0.10 \pm 0.006$ & 0.08 & 0.055 & $>0.99$ & $>0.99$ & 0.32 & 0.51 \\
\hline PSD length ( $\mu \mathrm{m})$ & $0.212 \pm 0.005$ & $0.214 \pm 0.005$ & $0.207 \pm 0.006$ & $0.249 \pm 0.008$ & $>0.99$ & $>0.99$ & 0.0037 & $>0.99$ & 0.0041 & 0.0398 \\
\hline Perforated PSD & $4.07 \%$ & $11.26 \%$ & $5.65 \%$ & $14.20 \%$ & $0.018^{b}$ & $0.58^{b}$ & $0.0013^{b}$ & $0.132^{b}$ & $0.021^{b}$ & $0.508^{b}$ \\
\hline
\end{tabular}

${ }^{a}$ Statistical analyses performed by nonparametric Kruskal-Wallis test with Dunn's test for multiple comparison. Number of microscopical fields: $\mathrm{V}(n=87) ; \mathrm{V}+\mathrm{T}(n=116) ; \mathrm{A} \beta(n=92) ; \mathrm{A} \beta+\mathrm{T}(n=113)$. For vesicle pool, docked vesicles, area of spines, and PSD length values are shown as mean \pm SEM. For perforated PSD, \% indicates the proportion of asymmetric synapses with perforated PSD.

${ }^{b}$ Statistical analysis performed by contingency analysis with Fisher's test. 
A

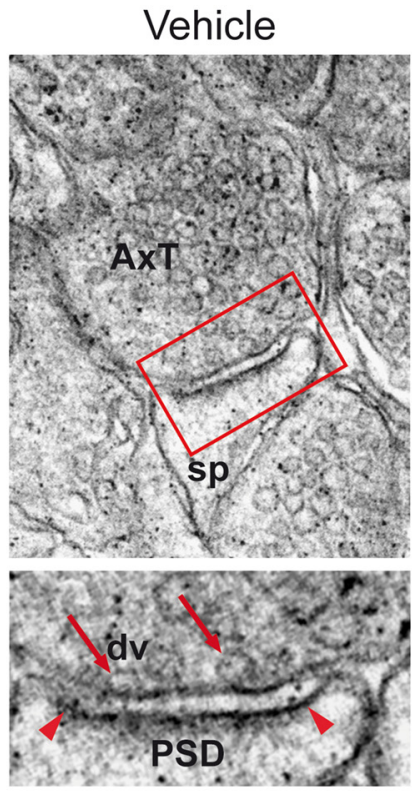

B

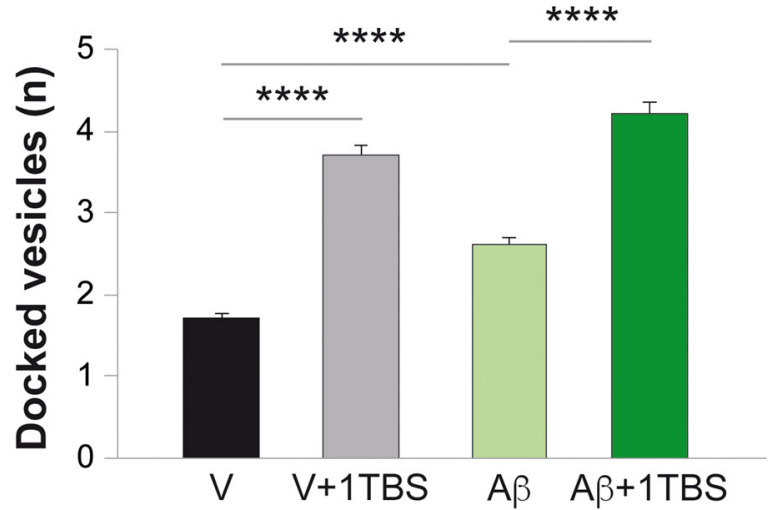

Vehicle, 1 TBS
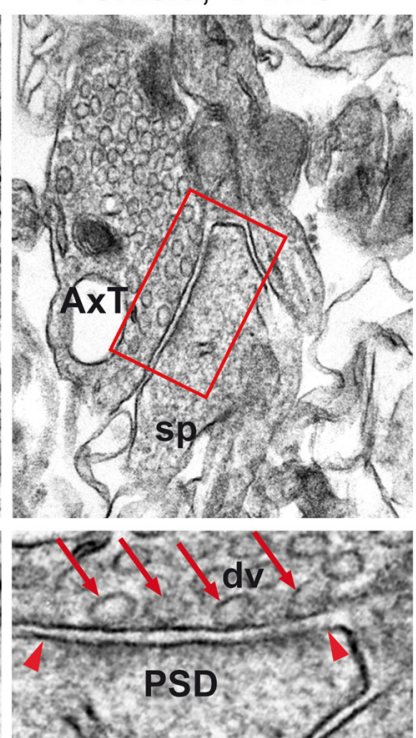

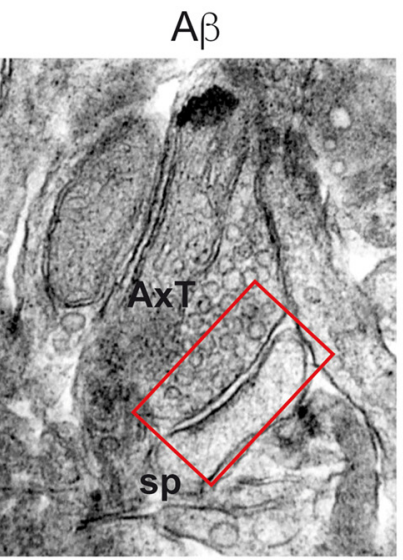

$\mathrm{A} \beta, 1 \mathrm{TBS}$
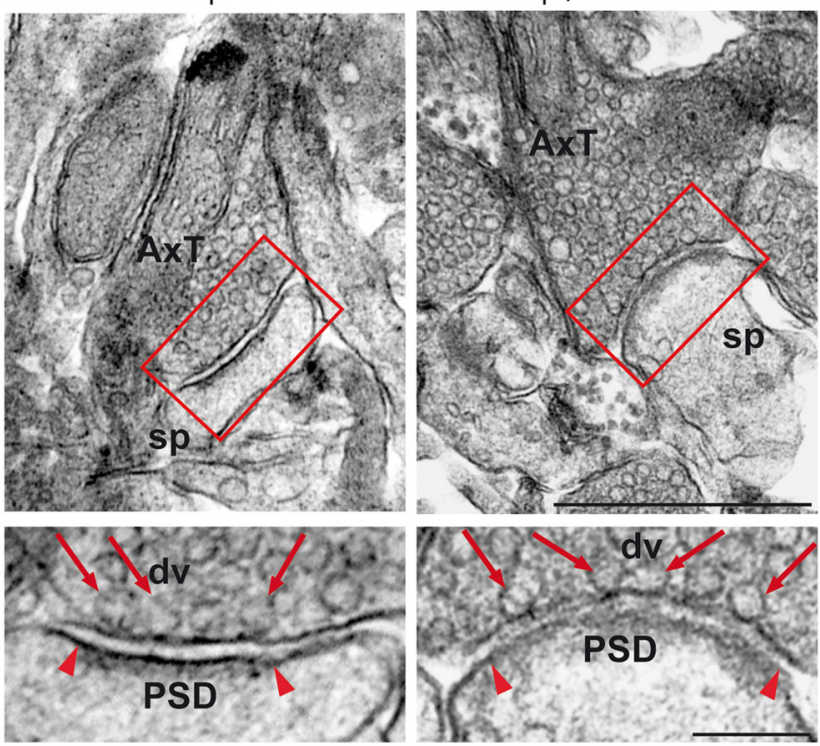

C

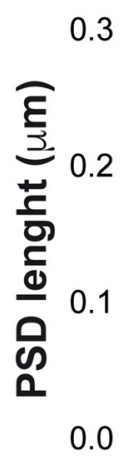

3
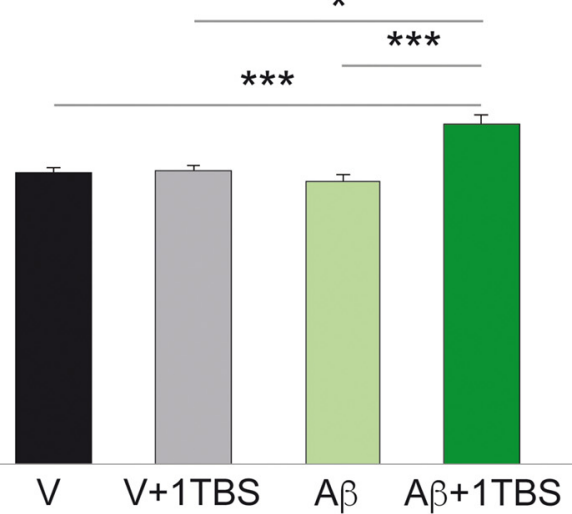

Figure 3. Picomolar concentrations of $\mathrm{OA} \beta_{42}$ increase the number of docked vesicles and PSD length. $A$, Representative asymmetric axospinous synapses of CA1 stratum radiatum from hippocampal slices previously treated for electrophysiological recordings. Framed regions enlarged (bottom) show the synaptic contact for each synapse from different experimental conditions. Arrows indicate docked vesicles (dv) at the active zone of axon terminals; arrowheads are the edges of PSD. AxT, Axon terminal; sp, spine. Scale bars: $500 \mathrm{~nm}$ for top, $100 \mathrm{~nm}$ for bottom. $\boldsymbol{B}, 0 \mathrm{~A} \beta_{42}$ alone increased the number $(n)$ of docked vesicles compared with vehicle $(p<0.0001)$. The number of docked vesicles increased in tetanized slices treated with $0 A \beta_{42}$ compared with nontetanized slices treated with the peptide, as well as in tetanized slices treated with vehicle versus vehicle-treated nontetanized ones $(p<0.0001)$. C, oA $\beta_{42}$ paired with a weak tetanic stimulation (1 TBS) increased PSD length compared with other conditions. See Table 1 for detailed results and statistical analyses. V, Vehicle, $A \beta=200$ рм $0 \mathrm{~A} \beta_{42,}, 1 \mathrm{TBS}=$ weak tetanic stimulation. ${ }^{*} p<0.05$; ${ }^{* * *} p<$ $0.005 ; * * * 0<0.0001$. Data are expressed as mean \pm SEM.

robustly support the electrophysiological data. Most importantly, this body of evidence indicates that synapses undergo a series of coordinated changes occurring both at the presynaptic and postsynaptic site following application of $\mathrm{oA} \beta_{42}$ at $\mathrm{pM}$ concentrations.

Effect of picomolar concentrations of $\mathrm{oA} \boldsymbol{\beta}_{42}$ on short-term and long-term synaptic plasticity and memory requires $\alpha 7$ nicotinic acetylcholine receptors $(\alpha 7 \mathrm{nAChRs})$

Because recent studies indicated that high nanomolar concentrations of extracellular oA $\beta_{42}$ require APP to impair LTP and memory (Puzzo et al., 2017; Wang et al., 2017), we tested whether the plasticity-enhancing effect of extracellular picomolar concentrations of $\mathrm{oA} \beta_{42}$ was APP dependent. We used APP-KO mice to determine whether the absence of endogenous APP prevented $200 \mathrm{pM} \mathrm{oA} \beta_{42}$ to exert its effects on PPF and LTP. We found that $200 \mathrm{pm} \mathrm{oA} \beta_{42}$ was still able to decrease PPF (Fig. $4 A$ ) and convert E-LTP into L-LTP (Fig. 4B) in APP-KO mice. Thus, unlike nano- molar concentrations of $\mathrm{A} \beta$, $\mathrm{pM}$ concentrations of the peptide did not require APP to produce their synaptic effects.

We then turned on $\alpha 7 \mathrm{nAChRs}$ because of their interplay with $\mathrm{A} \beta$ in physiological conditions (Puzzo et al., 2008, 2011; Zappettini et al., 2012; Lawrence et al., 2014). When slices from $\alpha 7$ nAChRs KO $(\alpha 7-\mathrm{KO})$ mice were treated with $200 \mathrm{pm} \mathrm{oA} \beta_{42}$, the decrease of PPF and the conversion of E-LTP to L-LTP were not elicited (Fig. 4C,D). To confirm that the effects of $200 \mathrm{pm}$ oA $\beta_{42}$ were mediated by $\alpha 7 \mathrm{nAChRs}$, we acutely blocked these receptors by the selective antagonist MLA. This prevented $200 \mathrm{pM}$ $\mathrm{oA} \beta_{42}$ from affecting PPF and LTP (Fig. $4 E, F$ ), suggesting that oA $\beta_{42}$ needs $\alpha 7 \mathrm{nAChRs}$ to exert its enhancing effects.

To corroborate our findings indicating that $\alpha 7 \mathrm{nAChRs,} \mathrm{but}$ not APP, were needed for $200 \mathrm{pM} \mathrm{oA} \beta_{42}$ to enhance plasticity, we repeated experiments after the acute block of $\alpha 7 \mathrm{nAChR}$ function with MLA, which prevented the $200 \mathrm{pM} \mathrm{oA} \beta_{42}$-mediated decrease of PPF and conversion of E-LTP into L-LTP in slices from APP-KO mice (Fig. 4G,H). 


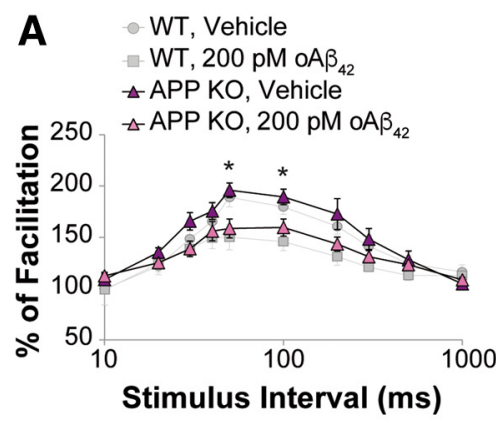

C $\quad ₫ \alpha 7 \mathrm{KO}$, Vehicle
$₫ \alpha 7 \mathrm{KO}, 200 \mathrm{pM} \circ \mathrm{A} \beta_{42}$

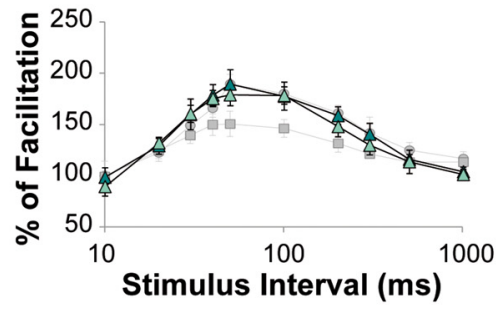

E

$\triangle W T, M L A, 200 \mathrm{pM} \circ \mathrm{A} \beta_{42}$
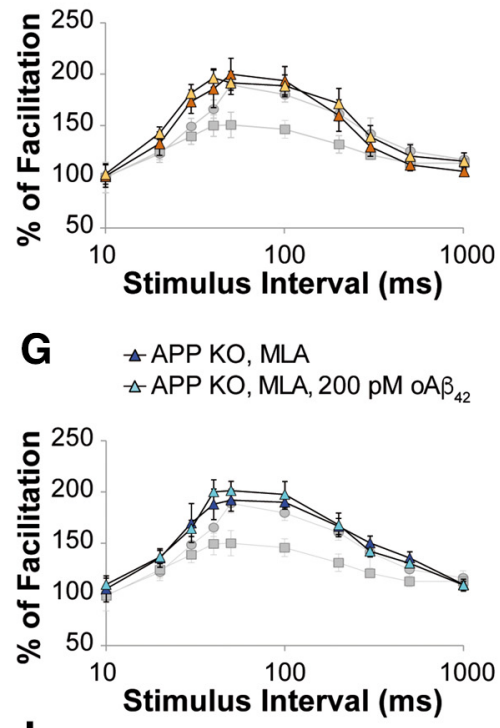

I

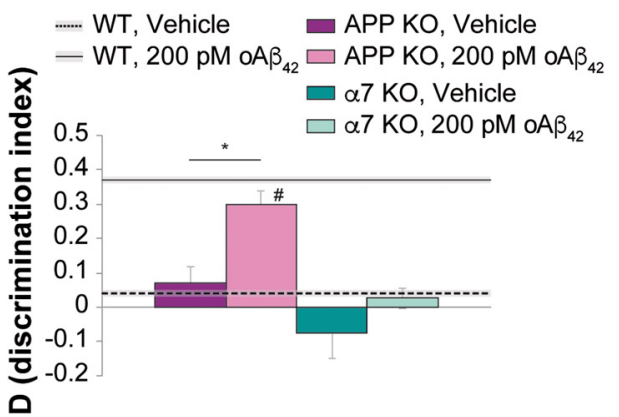

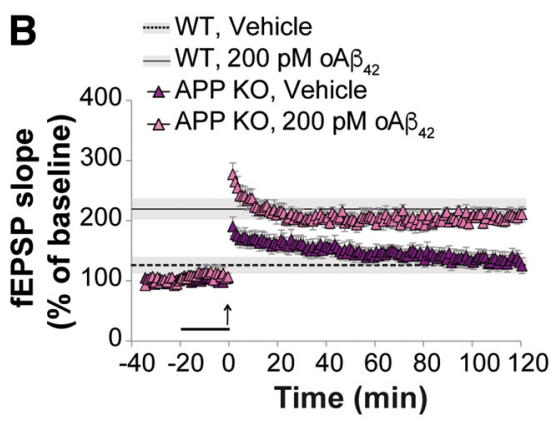
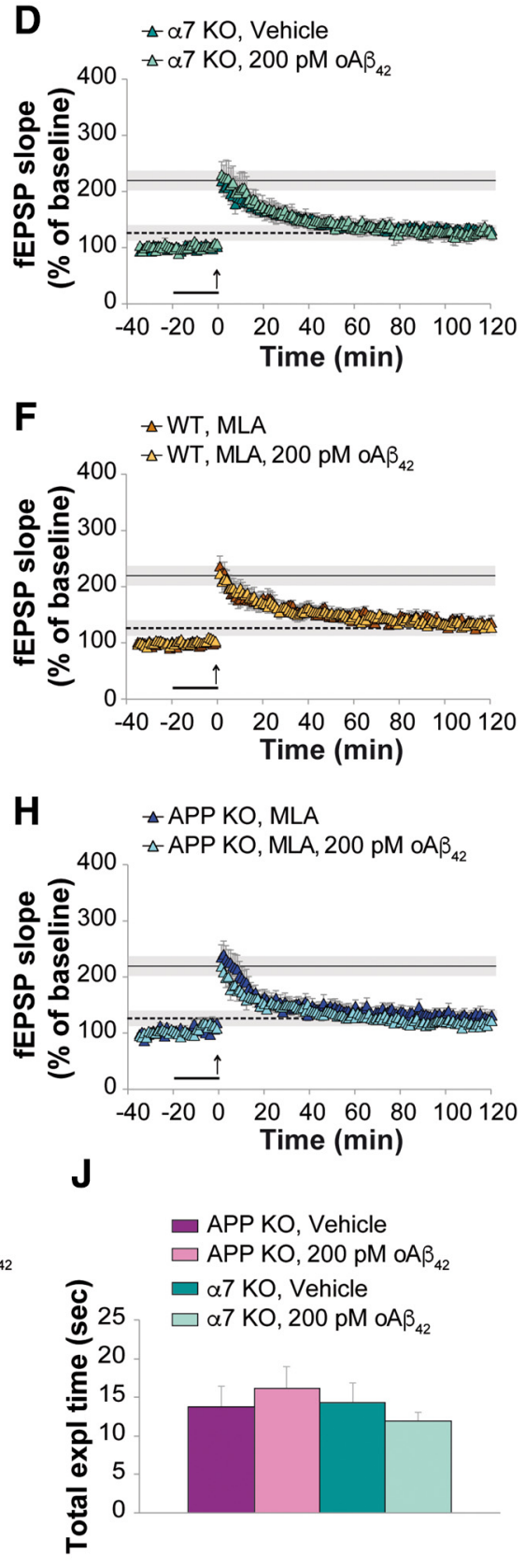

Figure 4. The $\alpha 7-n A C h R$, but not APP, is needed for picomolar concentrations of $0 A \beta_{42}$ to decrease PPF and convert both E-LTP into L-LTP and STM into LTM. $A$, Twenty-minute perfusion with $200 \mathrm{pm} 0 \mathrm{~A} \beta_{42}$ was capable of decreasing PPF in slices from APP-KO mice (\% facilitation at $100 \mathrm{~ms}$ interval here and in following panels: APP KO + vehicle $=189.34 \pm 7.51 \%, n=8 ; 200 \mathrm{pm} 0 \mathrm{~A} \beta_{42}$ $=159.57 \pm 8.32 \%, n=8 ;$ ANOVA for repeated measures $F_{(1,14)}=5.234, p=0.038$; Bonferroni's $p=0.013$ at $50 \mathrm{~ms}$ and 0.044 at $100 \mathrm{~ms})$. Gray shaded curves represent mean + SEM of PPF curves in WT slices treated with vehicle or $200 \mathrm{pm} 0 \mathrm{~A} \beta_{42}$ as shown in Figure 2. $\boldsymbol{B}, 200 \mathrm{pm} 0 \mathrm{~A} \beta_{42}$ converted E-LTP into L-LTP in slices from APP-K0 mice (124.69 $\pm 13.13 \%$ of baseline vs $210.28 \pm$ $12.60 \%$ of baseline, $n=7 / 7$; ANOVA for repeated measures $\left.F_{(1,12)}=14.77, p=0.002\right)$. Gray shaded areas with lines represent
Next, we validated our in vitro and ex vivo results in vivo by investigating whether APP and/or $\alpha 7 \mathrm{nAChRs}$ were needed for $200 \mathrm{pM} \mathrm{oA} \beta_{42}$ to convert STM into LTM. APP-KO and $\alpha 7-\mathrm{KO}$ mice were injected intrahippocampally with vehicle or $200 \mathrm{pM} \mathrm{oA} \beta_{42}$ before training (short exposure in T1) and memory was evaluated after $24 \mathrm{~h}$. Analyses of the discrimination index revealed that $200 \mathrm{pM} \mathrm{oA} \beta_{42}$ was capable to induce LTM in APP-KO but not in $\alpha 7-\mathrm{KO}$ mice (Fig. $4 I$ ), without modifying total exploration time (Fig. $4 J)$. Thus, $\alpha 7 \mathrm{nAChRs}$, but not APP, were necessary for $\mathrm{pM} \mathrm{oA} \beta_{42}$ to convert STM into LTM.

oA $\boldsymbol{\beta}_{42}$-induced conversion of early-LTP into late-LTP and STM into LTM depends upon the nitric oxide (NO)/ cGMP/protein kinase G (PKG) pathway and involves plasticity-related proteins (PRPs)

To gain insight into the intracellular mechanisms involved in the oA $\beta_{42}$ induced enhancement of LTP, we focused on the NO/cGMP/PKG pathway, which plays a key role in presynaptic and postsynaptic mechanisms of plasticity and in

\section{$\leftarrow$}

mean + SEM of the last recorded point of 1 TBS-induced LTP in WT slices treated with vehicle or $200 \mathrm{pm} 0 \mathrm{~A} \beta_{42}$ as shown in Figure 2; the arrow indicates 1 TBS in this and the following panels. C, $200 \mathrm{pm} 0 \mathrm{~A} \beta_{42}$ did not affect PPF in slices from $\alpha 7-\mathrm{KO}$ mice $\left(177.42 \pm 13.67 \%\right.$ vs $178.03 \pm 8.52 \%, n=8 / 8 ; F_{(1,16)}$ $=0.388, p=0.542) \cdot D, 200$ pm $0 A \beta_{42}$ did not convert E-LTP into L-LTP in slices from $\alpha 7-K 0$ mice $(131.12 \pm 3.46 \%$ of baseline vs $124.43 \pm 11.09 \%$ of baseline, $n=7 / 7 ; F_{(1,12)}=$ $0.002, p=0.964) . E, 200$ pм $0 A \beta_{42}$ did not affect PPF in slices from WT mice treated with the $\alpha 7 \mathrm{nAChR}$ antagonist MLA (10 nм, 10 min before tetanus) (192.99 $\pm 13.84 \%$ vs $188.02 \pm$ $\left.10.54 \%, n=11 / 11 ; F_{(1,20)}=0.154, p=0.699\right) . F, 200$ pм $0 \mathrm{~A} \beta_{42}$ did not convert E-LTP into L-LTP in slices from WT mice treated with MLA (137.45 $\pm 12.25 \%$ of baseline vs $128.57 \pm$ $3.81 \%$ of baseline, $\left.n=6 / 7 ; F_{(1,11)}=0.009, p=0.927\right)$. $\mathbf{G}$, 200 рм $0 \mathrm{~A} \beta_{42}$ did not modify PPF in APP-KO mice treated with $\operatorname{MLA}\left(189.90 \pm 6.86 \%\right.$ vs $197.38 \pm 12.64 \%, n=6 / 10 ; F_{(1,14)}$ $=0.001, p=0.973) . \boldsymbol{H}, 200$ pM $0 A \beta_{42}$ did not convert E-LTP into L-LTP in slices from APP-KO mice treated with MLA $(130.70 \pm 9.68 \%$ of baseline vs $121.18 \pm 7.35 \%$ of baseline, $\left.n=6 / 7 ; F_{(1,11)}=0.589, p=0.459\right) . I$, Intrahippocampal injections with 200 pм oA $\beta_{42} 20$ min before a short T1 converted STM into LTM in APP-KO mice ( $D=0.06 \pm 0.04$ vs $0.30 \pm 0.03 ; n=10 / 10$ sex-balanced mice; Bonferroni's $p=$ 0.022 comparing APP-K0 mice treated with vehicle or $200 \mathrm{pm}$ $0 \mathrm{~A} \beta_{42} ; t_{(9)}=7.645, p<0.0001$ comparing $D$ vs zero in APP $\left.\mathrm{K} 0+200 \mathrm{pm} 0 \mathrm{~A} \beta_{42}\right)$. Conversely, $200 \mathrm{pm} 0 \mathrm{~A} \beta_{42}$ administration did not induce LTM in $\alpha 7-K 0$ mice ( $D=-0.07 \pm 0.07$ vs $0.02 \pm 0.02 ; n=10 / 10$ sex-balanced mice; Bonferroni's $p=$ 1 comparing $\alpha 7-\mathrm{KO}$ mice treated with vehicle or $200 \mathrm{pm}$ $0 \mathrm{~A} \beta_{42} ; t_{(9)}=0.999, p=0.344$ comparing $\mathrm{D}$ vs zero in $\alpha 7 \mathrm{KO}$ $\left.+200 \mathrm{pm} 0 \mathrm{~A} \beta_{42}\right)$.J, Total exploration time was comparable in the 4 groups of mice $\left(F_{(3,36)}=0.515, p=0.674\right) .{ }^{*} p<0.05$; \# difference from 0 . Data are expressed as mean \pm SEM. 
A

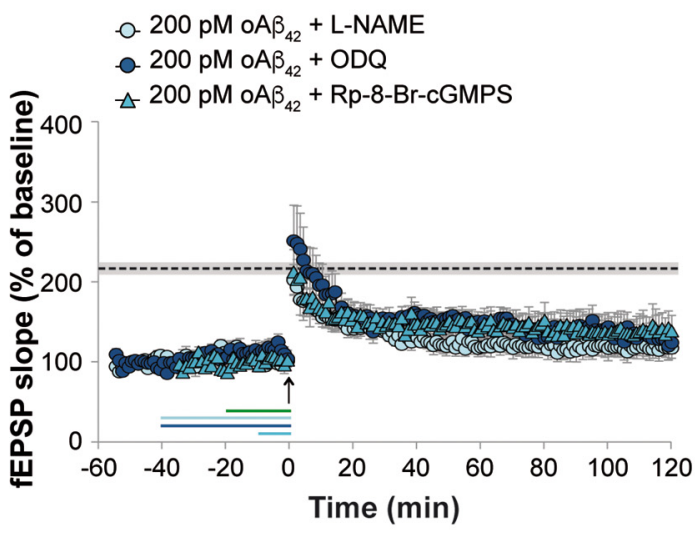

B

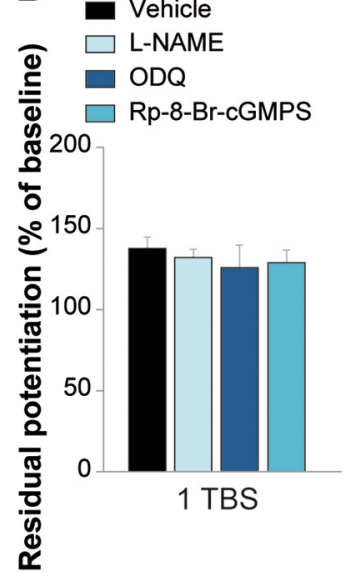

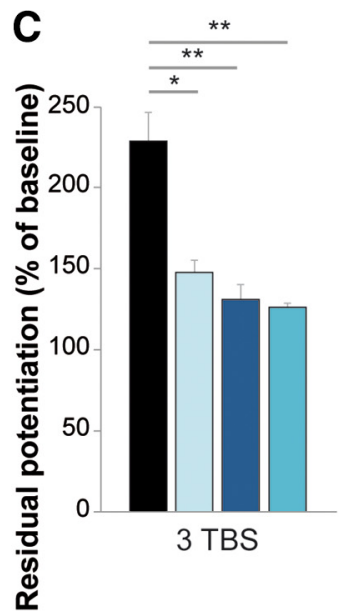

D
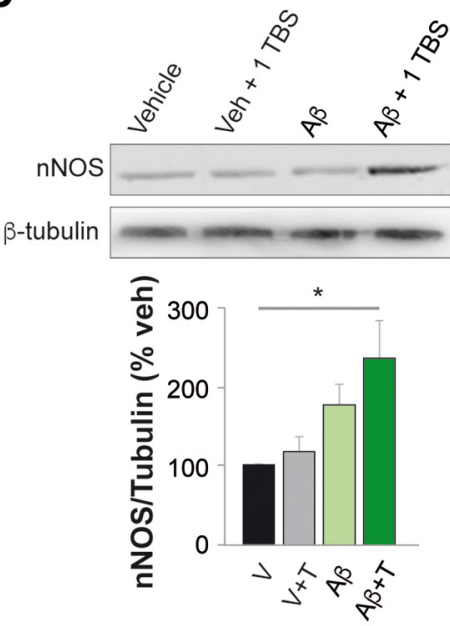

E

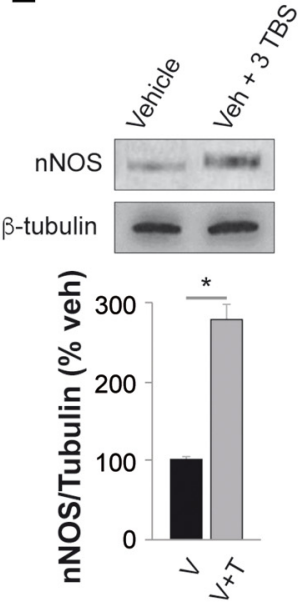

$\mathbf{F}$

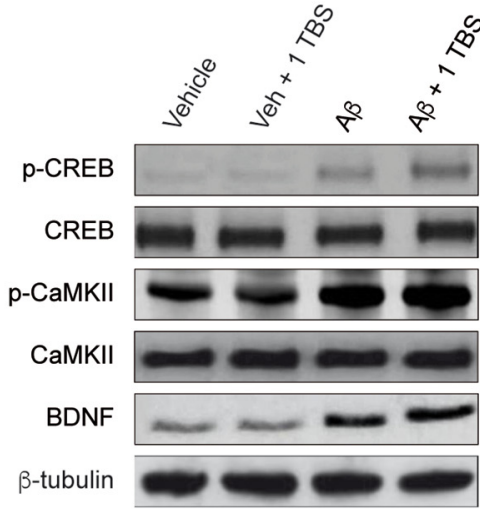

G

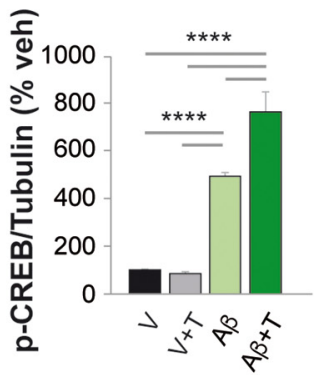

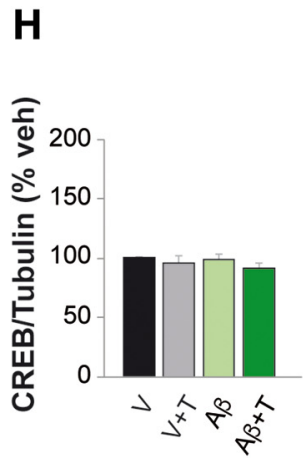
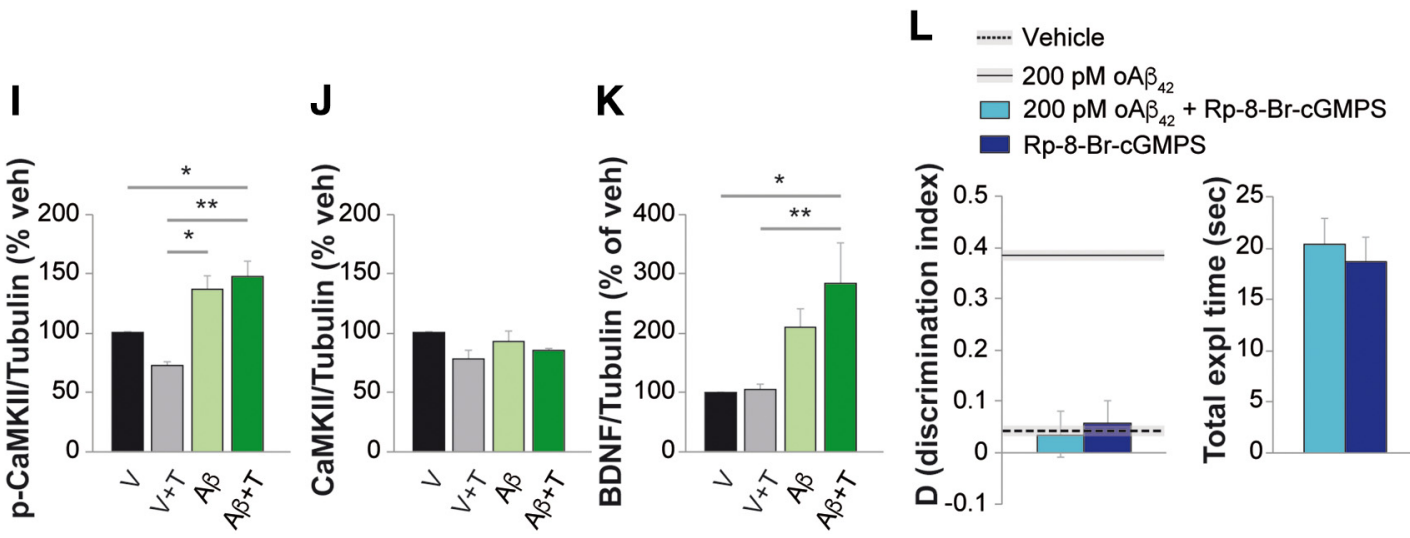

Figure 5. Conversion of E-LTP into L-LTP and STM into LTM by pM $0 A \beta_{42}$ is mediated through the NO/CGMP/PKG cascade. $A, 200 \mathrm{pm} 0 A \beta_{42}$ did not induce L-LTP in slices treated with the nNOS inhibitor L-NAME (100 $\mu \mathrm{m}$ for $40 \mathrm{~min})\left(118.96 \pm 12.57 \%\right.$ of baseline, $n=7 ; F_{(1,12)}=18.645, p=0.001$ vs $200 \mathrm{pm} \mathrm{OA} \beta_{42}+1$ TBS), the sGC inhibitor ODQ (100 $\mu \mathrm{m}$ for $\left.40 \mathrm{~min}\right)(125.84 \pm 13.39 \%$ of baseline, $\left.n=6 ; F_{(1,11)}=8.903, p=0.012\right)$, and the PKG inhibitor Rp-8-Br-GGMS (10 $\mu \mathrm{m}$ for $\left.10 \mathrm{~min}\right)\left(140.48 \pm 19.61 \%\right.$ of baseline, $\left.n=7 ; F_{(1,12)}=9.161, p=0.011\right)$. Shaded area with line corresponds to mean \pm SEM of the last recorded point in WT slices treated with $200 \mathrm{pm} \mathrm{OA} \beta_{42}+1$ TBS as in Figure 2. B, Treatment with L-NAME, 0DQ, or Rp-8Br-CGMPS alone did not modify residual potentiation induced by a weak tetanic stimulation compared with vehicle $\left(n=4\right.$ for each condition, $\left.F_{(1,12)}=0.315, p=0.814\right)$. C, Blocking the NO/CGMP/PKG pathway inhibits L-LTP induced by a strong tetanic stimulation compared with vehicle $\left(n=4\right.$ for each condition, $F_{(3,14)}=13.391, p<0.0001$ among all; vehicle: $228.15 \pm 18.80 \%$ of baseline; L-NAME: $148.44 \pm 7.45 \%$ of baseline, Bonferroni's $p=0.006 ; 0 D Q: 131.24 \pm 9.22 \%$ of baseline, Bonferroni's $p=0.001 ;$ Rp-8Br-CGMPS: $126.15 \pm 2.54 \%$ of baseline, Bonferroni's $p=0.001)$. D, Top, Representative images of WB assay (cropped images based on MW) performed on hippocampal slices ( $n=4$ for each lane) treated for electrophysiological experiments, collected, and stored at 120 min after treatment (V, vehicle; T, $1 \mathrm{TBS} ; \mathrm{A} \beta=0 \mathrm{AA} \beta_{42} 200 \mathrm{pm}$ ). Bottom, Bar graph obtained by the average of two or three different membranes here in $\boldsymbol{E}$ and in $\boldsymbol{G}$. $\beta$-Tubulin expression is shown as one example of loading control. An increase of nNOS expression $\left(F_{(3,8)}=4.570 ; p=0.038\right.$; Tukey's $\left.p=0.042\right)$ was detected in slices treated with A $\beta$ and a 1 TBS stimulation. $E$, nNOS expression increased in slices treated with vehicle and 3TBS $\left(F_{(1,2)}=52.412 ; p=0.019\right)$. $\boldsymbol{F}$, WB assay of PRPs. $\boldsymbol{G}, \mathrm{p}$-CREB expression was increased after treatment with $\mathrm{A} \beta$ alone and further enhanced in $\mathrm{A} \beta+\mathrm{T}\left(F_{(3,12)}=61.713 ; p<\right.$ $0.0001 ;$ Tukey's $p<0.0001)$. $\boldsymbol{H}$, No changes were detected in total CREB expression among different conditions $\left(F_{(3,4)}=0.930 ; p=0.504\right) . \boldsymbol{I}, J$, A $\beta$ paired with 1 TBS increased $p$-CaMKII levels $\left(F_{(3,8)}\right.$ $=11.746 ; p=0.003)$ compared with $\mathrm{V}(p=0.017)$ or $\mathrm{V}+\mathrm{T}(p=0.004)(I)$, whereas CaMKII expression was not modified $\left(\boldsymbol{J} ; F_{(3,4)}=2.758 ; p=0.176\right) . \boldsymbol{K}, \mathrm{A} \beta$ paired with $1 \mathrm{TBS}$ increased BDNF levels $\left(F_{(3,8)}=5.686 ; p=0.022\right)$ compared with $\mathrm{V}(p=0.034)$ and $\mathrm{V}+\mathrm{T}(p=0.038)$. $L$, Evaluation of recognition memory indicated that $200 \mathrm{pm} 0 \mathrm{~A} \beta_{42}$ did not induce $L T M$ in mice concurrently treated with the PKG inhibitor Rp-8-Br-cGMPS [discrimination index $(D)=0.03 \pm 0.044, n=10$ sex-balanced mice for each condition; $t_{(9)}=0.735, p=0.481$ (Figure legend continues.) 
the conversion from E-LTP to L-LTP (Bon and Garthwaite, 2003; Johnstone and Raymond, 2011). To this end, hippocampal slices were treated with $200 \mathrm{pM}$ $\mathrm{oA} \beta_{42}$ paired with drugs able to inhibit NO or cGMP production or PKG activation. When preventing NO production by using the inhibitor of the nNOS L-NAME, the inhibitor of soluble guanylyl cyclase ODQ, or the cGMP analog Rp-8-BrcGMPS, oA $\beta_{42}$ failed to induce a longlasting potentiation (Fig. 5A). Control experiments showed that L-NAME, ODQ, and Rp-8-Br-cGMPS did not disrupt LTP evoked by a weak tetanic stimulation per se (Fig. 5B), whereas they impaired L-LTP induced by a 3 TBS stimulation (Fig. $5 C$ ), further suggesting that pM oA $\beta_{42}$ acts via a pathway that is physiologically involved in L-LTP formation.

Because electrophysiological data showed an involvement of the NO/cGMP/PKG pathway, we performed Western blots on slices from electrophysiology experiments to evaluate whether oA $\beta_{42}$ triggers $\mathrm{NO}$ production by affecting nNOS expression. We found a significant increase of $\mathrm{nNOS}$ in slices treated with $200 \mathrm{pm} \mathrm{oA} \beta_{42}$ paired with a weak tetanus (Fig. $5 D$ ), similar to that obtained in slices treated with vehicle paired with a strong tetanus (Fig. 5E).

Furthermore, we explored the molecular mechanisms underlying oA $\beta_{42}$-induced L-LTP by analyzing the expression of PRPs, known to be involved in synaptic plasticity and memory (Puzzo et al., 2016), including cAMP-responsive element binding protein (CREB), calcium-calmodulin-dependent protein kinase II $\alpha$ (CaMKII), and brainderived neurotrophic factor (BDNF), in the same hippocampal slices used for electrophysiological experiments. We found that cAMP-responsive element binding protein (CREB) phosphorylated at Ser

133 (p-CREB) was increased in slices treated with oA $\beta_{42}$ alone or $\mathrm{oA} \beta_{42}$ paired with a weak tetanic stimulation without affecting total CREB levels (Fig. $5 F-H$ ). oA $\beta_{42}$ also increased the expression of the CaMKII phosphorylated at Thr 286 (p-CaMKII) (Fig. $5 F, I, J)$ and $\mathrm{BDNF}$ (Fig. $5 F, K$ ).

Finally, because the NO/cGMP/PKG pathway has been widely demonstrated to intervene in memory processes and previous studies have suggested that PKG activity maintains CREB phosphorylation at Ser133 during memory consolidation (Puzzo et al., 2016), we investigated whether the oA $\beta_{42}$-induced conversion of STM into LTM depends upon PKG activity. As for LTP,

$\leftarrow$

(Figure legend continued.) comparing D vs zero; Bonferroni's $p<0.0001$ comparing D between 200 рм оA $\beta_{42}$ vs 200 pм оA $\beta_{42}+$ Rp-8-Br-cGMPS]. Rp-8-Br-cGMPS alone did not affect STM (Bonferroni's $p=1$ vs vehicle). Total exploration time (right) was not modified by treatments $\left(F_{(2,27)}=0.086, p=0.667\right)$. Shaded area with lines corresponds to mean $+S E M$ of $D$ in mice treated with vehicle or $200 \mathrm{pm} 0 \mathrm{~A} \beta_{42} 20$ min before a short T1 exposure. ${ }^{*} p<0.05$; ${ }^{* *} p<$ $0.01 ; * * * 0<0.0001$. Data are expressed as mean $\pm \mathrm{SEM}$. we found that treatment with the cGMP analog Rp-8-Br-cGMPS prevented $\mathrm{oA} \beta_{42}$ to induce LTM in mice that underwent a short exposure during the training phase (Fig. $5 L$ ), whereas Rp-8-Br-cGMPS did not affect STM per se (Fig. $5 L$ ). Thus, PKG activation mediates $\mathrm{oA} \beta_{42}$-induced conversion of STM into LTM.

Overall, our findings indicate that oA $\beta_{42}$ mainly acts via an intracellular signaling pathway involving the $\mathrm{NO} / \mathrm{cGMP} / \mathrm{PKG}$ pathway leading to PRP activation, synaptic potentiation, and memory formation, as summarized in Figure 6.

\section{Discussion}

We focused on the role of picomolar concentrations of $\mathrm{oA} \beta_{42}$ at hippocampal synapses in the healthy rodent brain. We found that $200 \mathrm{pm} \mathrm{oA} \beta_{42}$ increases neurotransmitter release, induces presynaptic and postsynaptic ultrastructural changes, and increases PRP expression, leading to the conversion of E-LTP into L-LTP and of STM into LTM.

This study was inspired by previous observations indicating that $\mathrm{oA} \beta_{42}$ exerts opposite effects onto synaptic plasticity and 
memory depending upon its concentration (Puzzo et al., 2012; Gulisano et al., 2018b). Here, we first performed a DR curve to confirm that $200 \mathrm{pM} \mathrm{oA} \beta_{42}$ was the dose capable of enhancing LTP, whereas $200 \mathrm{~nm}$ impaired it, consistent with previous works (Puzzo et al., 2008, 2011, 2012; Garcia-Osta and Alberini, 2009; Morley et al., 2010; Lazarevic et al., 2017).

Next, because high concentrations of extracellular oA $\beta_{42}$ enter neurons (Ripoli et al., 2014; Puzzo et al., 2017), leading to synaptic dysfunction through direct intracellular targets (Ripoli et al., 2014), we investigated whether pм оА $\beta_{42}$ acts at extracellular and/or intracellular levels when enhancing synaptic transmission and plasticity. We demonstrated that the effect of pM $\mathrm{oA} \beta_{42}$ is exerted only when the peptide is applied extracellularly, because its administration inside neurons did not affect LTP. Dual-patch experiments, in which we applied oA $\beta_{42}$ from the extracellular space while one of the two adjacent neurons was injected with the $6 \mathrm{E} 10$ antibody to neutralize human oA $\beta_{42}$ possibly accumulated inside neurons, confirmed that only extracellular oA $\beta_{42}$ enhances mEPSC frequency.

The increase in mEPSC frequency and the decrease in PPF suggest a presynaptic mechanism of neurotransmitter release, consistent with previous electrophysiological findings showing that $\mathrm{pM} \mathrm{oA} \beta_{42}$ affect basal synaptic transmission, inducing an increase of fiber volley amplitude, an index of presynaptic recruitment (Gulisano et al., 2018b), and posttetanic potentiation, a form of short-term plasticity due to presynaptic calcium entry (Puzzo et al., 2008). Furthermore, it has been recently demonstrated that $\mathrm{A} \beta$ exerts an opposite effect on synaptic vesicle recycling depending upon the dose (Lazarevic et al., 2017), consistent with other studies showing a sustained increase of mEPSC frequency after prolonged exposure to $200 \mathrm{pM}$ oA $\beta_{42}$ (Koppensteiner et al., 2016) or treatment with inhibitors of $\mathrm{A} \beta$ degradation (Abramov et al., 2009). In these circumstances, high levels of $\mathrm{A} \beta$ may maintain neurotransmitter release for a longer period, leading to vesicle depletion (Parodi et al., 2010), or enter neurons directly, affecting presynaptic proteins such as synaptophysin, VAMP2, or synapsin I (Russell et al., 2012; Koppensteiner et al., 2016).

Here, we show that both exogenously applied human $\mathrm{A} \beta$ at low concentrations and endogenous $\mathrm{A} \beta$ are involved in neurotransmitter release. This is consistent with previous studies demonstrating that endogenous $A \beta$ is needed for synaptic plasticity and memory to occur (Garcia-Osta and Alberini, 2009; Morley et al., 2010; Puzzo et al., 2011) and that $\mathrm{A} \beta$ production physiologically increases during neuronal activity and memory induction (Kamenetz et al., 2003; Cirrito et al., 2005; Brody et al., 2008; Puzzo et al., 2011; Palmeri et al., 2017). Interestingly, we have previously demonstrated that the impairment of LTP and memory due to the inhibition of endogenous $A \beta$ could be rescued by concomitant application of exogenous $200 \mathrm{pm} \mathrm{A} \beta$, with $300 \mathrm{pm} \mathrm{A} \beta$ producing a more pronounced enhancement similar to that obtained with the administration of 200 pM exogenous A $\beta$ alone (Puzzo et al., 2011). In the same work, we demonstrated that the threshold of $A \beta$ needed for normal synaptic plasticity and memory is $\sim 330-380 \mathrm{pm}$. Thus, considering that $\mathrm{A} \beta_{42}$ levels in basal conditions are equal to 180-200 pM (Puzzo et al., 2008), adding $200 \mathrm{pm}$ exogenous $\mathrm{A} \beta$ is likely to induce a further enhancement of synaptic plasticity and memory. Even if we cannot exclude that exogenously applied and endogenous $\mathrm{A} \beta$ might use different mechanisms to act, previous works have suggested that a common target might be represented by $\alpha 7$-nAchRs (Puzzo et al., 2008, 2011), the genetic or pharmacological deletion of which prevented both endogenous or exogenous $\mathrm{A} \beta$ to exert its effects at the synapse.

Because the probability of transmitter release contributes to LTP induction and maintenance (Kleschevnikov et al., 1997), we investigated whether oA $\beta_{42}$ converted E-LTP into L-LTP, two different forms of plasticity characterized by different temporal and mechanistic features (Huang, 1998). E-LTP can be induced by a weak tetanic stimulation, decays in 1 or $2 \mathrm{~h}$, does not depend on new protein synthesis, and is mostly due to activation of kinases. Conversely, L-LTP needs a stronger stimulation to be induced, lasts several hours, and requires new protein synthesis and gene transcription (Bliss and Collingridge, 1993; Nguyen et al., 1994; Huang, 1998). Several studies have demonstrated that adequate physiological or pharmacological stimuli might convert E-LTP into L-LTP, a mechanism that parallels transformation of STM into LTM (for review, see Puzzo et al., 2016). Here, we found that treatment with picomolar concentrations of oA $\beta_{42}$ before a weak tetanic stimulation converted E-LTP into L-LTP and STM into LTM, suggesting that, at this concentration, the peptide acts as a cognitive enhancer and further begging the question of how its removal from the brain might be beneficial.

Ultrastructural analyses of hippocampal slices treated as for electrophysiology revealed that $\mathrm{oA} \beta_{42}$ produces a series of concomitant changes occurring both presynaptically and postsynaptically, as one would expect for long-term normal synaptic plasticity to occur (Antonova et al., 2001). Indeed, oA $\beta_{42}$ alone elevated the fraction of vesicles available for release (i.e., docked vesicles) during the induction of plasticity (Bourne et al., 2013), whereas a longer PSD, which is suggestive of plastic changes occurring at the postsynaptic site (Babits et al., 2016), was observed in slices treated with oA $\beta_{42}$ paired with a weak tetanus.

In the present study, we also sought to explore the possible extracellular targets used by $\mathrm{pM} \mathrm{оA} \beta_{42}$ to affect PPF and convert E-LTP into L-LTP. We first focused on APP because it binds different A $\beta$ species (Lorenzo et al., 2000; Shaked et al., 2006; Fogel et al., 2014) and is involved in the enhancement of neurotransmitter release, leading to hippocampal hyperactivity in AD (Bakker et al., 2012; Busche et al., 2012).

Furthermore, recent studies have shown that, at high concentrations, extracellular A $\beta$ needs APP to impair synaptic plasticity and memory (Puzzo et al., 2017; Wang et al., 2017). Here, we used APP-KO mice at young age, when the impairment of LTP and memory is not yet manifested (Dawson et al., 1999; Tyan et al., 2012), to investigate whether A $\beta$ needs APP to enhance synaptic plasticity and memory when at low concentration. Because $\mathrm{pM}$ $\mathrm{oA} \beta_{42}$ still enhanced neurotransmitter release, synaptic plasticity, and memory in APP-KO mice, we concluded that APP intervenes in $\mathrm{A} \beta$ detrimental effects when the peptide is present at high concentrations (Puzzo et al., 2017), but is not needed for $\mathrm{oA} \beta_{42}$ at low concentrations to enhance synaptic plasticity.

Because $A \beta$ induces a series of events mediated by an increase of $\mathrm{Ca}^{2+}$ entry in the presynaptic terminal (Puzzo et al., 2008; Lawrence et al., 2014), we focused on $\alpha 7 \mathrm{nAChRs,} \mathrm{ionotropic}$ channels permeable to calcium that are highly expressed in the hippocampus and implicated in a variety of cognitive functions such as learning and memory, attention and reward (for review, see Picciotto et al., 2000). The link between $\mathrm{A} \beta$ and $\alpha 7 \mathrm{nAChRs}$ has been widely studied and it is known that $\mathrm{A} \beta$ binds $\alpha 7 \mathrm{nAChRs}$ with high affinity, exerting an agonistic or antagonistic effect in a dose-dependent manner (Wang et al., 2000; Mura et al., 2012). Using genetic and pharmacological approaches, we showed that $\alpha 7 \mathrm{nAChRs}$ are needed for $\mathrm{pm} \mathrm{oA} \beta_{42}$ to increase neurotransmitter release and to consolidate LTP. Experiments performed in hip- 
pocampal slices from APP-KO mice treated with the $\alpha 7 \mathrm{nAChR}$ antagonist MLA further confirmed that, at low concentrations, oA $\beta_{42}$ exerts its effect through $\alpha 7 \mathrm{nAChRs}$ and not APP, in agreement with previous studies (Puzzo et al., 2008, 2011; Mura et al., 2012; Lawrence et al., 2014).

The in vitro observation showing that $\alpha 7 \mathrm{nAChRs}$ but not APP are necessary for pM $\mathrm{oA} \beta_{42}$ to produce L-LTP was further confirmed by in vivo studies demonstrating that the $\mathrm{oA} \beta_{42}$-induced conversion of STM into LTM relies upon $\alpha 7 \mathrm{nAChRs}$ and does not involve APP.

Here, we also demonstrated that $\mathrm{oA} \beta_{42}$ effects are mediated by the $\mathrm{NO} / \mathrm{cGMP} / \mathrm{PKG}$ cascade, already known to be involved in LTP and memory induction and maintenance (Johnstone and Raymond, 2011; Bollen et al., 2014). In fact, inhibition of this pathway prevented oA $\beta_{42}$-induced L-LTP and LTM. Interestingly, we have recently demonstrated that in physiological conditions, cGMP stimulates $\mathrm{A} \beta$ production to induce L-LTP and memory (Palmeri et al., 2017). This, together with the present results, indicates that the $\mathrm{NO} / \mathrm{cGMP}$ pathway acts both upstream and downstream of $A \beta$, suggesting the existence of a cGMP-A $\beta$ cGMP loop as a preferential intracellular mechanism involved in $\mathrm{A} \beta$-mediated plastic effects.

Additionally, pM oA $\beta_{42}$ increased the expression of nNOS, which is decreased by high concentrations of the peptide (Venturini et al., 2002). This effect might be due to direct or indirect mechanisms. Indeed, previous studies have demonstrated that $\mathrm{A} \beta$ fragments can bind nNOS (Padayachee and Whiteley, 2011), suggesting the possibility of a direct interaction between the two proteins. Conversely, the oA $\beta_{42}$-induced increase of neurotransmitter release might enhance $\mathrm{Ca}^{2+}$ influx at the postsynaptic level, triggering increased nNOS expression (Sasaki et al., 2000).

The $\mathrm{oA} \beta_{42}$-induced conversion of E-LTP into L-LTP suggests a possible role for $A \beta$ in the synaptic tagging mechanism. Synapses that have received a weak stimulation enter a receptive state (tagging) that, if associated with the synthesis of PRPs, will lead to LTP maintenance. The initial changes in the synaptic weight are given by the efficacy of the presynaptic and postsynaptic elements and require a third factor to persist (Redondo and Morris, 2011). Consistent with this possibility, pretreatment of hippocampal slices with $\mathrm{oA} \beta_{42}$ induced the synaptic changes underlying L-LTP, such as the increased phosphorylation of CREB known to lead to PRP expression needed for L-LTP appearance (Bourtchuladze et al., 1994). Moreover, p-CREB further increased in slices in which $\mathrm{oA} \beta_{42}$ was paired with a weak tetanus, confirming that CREB phosphorylation continues to rise during LTP maintenance (Leutgeb et al., 2005) and that the NO/cGMP/PKG cascade can trigger gene expression through CREB phosphorylation during L-LTP (Lu et al., 1999).

Interestingly, pairing $\mathrm{oA} \beta_{42}$ with a weak tetanus induced an increase of CaMKII phosphorylation and BDNF expression, molecules known to stimulate CREB activation, thus inducing L-LTP and LTM. In particular, p-CaMKII, like nNOS, responds to NMDA-receptor-mediated $\mathrm{Ca}^{2+}$ entry during LTP and is involved in tag signaling (Lisman et al., 2012) and metaplasticity (Deisseroth et al., 1995); BDNF is responsible for upregulating gene transcription and promoting structural changes during L-LTP (Bekinschtein et al., 2007). This further suggests that $\mathrm{oA} \beta_{42}$ may prime the synapse to be more responsive, as also indicated by ultrastructural results.

In conclusion, our findings evidenced interesting differences and similarities between low versus high oA $\beta_{42}$ concentrations. Indeed, the effects of picomolar concentrations of $\mathrm{A} \beta_{42}$ are exerted at the extracellular level and depend upon $\alpha 7 \mathrm{nAChRs,}$ whereas nM oA $\beta_{42}$ requires APP and intraneuronal internalization (Ripoli et al., 2014; Puzzo et al., 2017), even if it is not possible to exclude an extracellular effect mediated by different receptors. Conversely, low and high oA $\beta_{42}$ levels affect the same key intracellular pathways involved in synaptic plasticity and memory (i.e., the NO/cGMP/PKG/p-CREB cascade, CaMKII, $\mathrm{BDNF}$ ), leading to their stimulation at picomolar concentrations or inhibition at nanomolar concentrations (Puzzo et al., 2005, 2009; Ghosh and Giese, 2015; Song et al., 2015; Opazo et al., 2018). The capability of $\mathrm{oA} \beta_{42}$ to induce opposite effects depending upon its dose is consistent with previous studies (Calabrese, 2001; Puzzo et al., 2012), and this biphasic behavior characterized by low-dose stimulation and high-dose inhibition might be framed into the "hormesis" phenomenon (Calabrese, 2008; Mattson, 2008). Indeed, even if the most used approach to model a DR curve is the linear Hill model, several studies have pointed out that it might not be sufficient to explain the multiphasic response exerted by a variety of endogenous or exogenous compounds (for review, see Prickaerts et al., 2017). Although different mechanisms may underlie the hormetic effect (Mattson, 2008), it is widely accepted that a compound might interact with a certain target depending upon its concentration. Consistently, $\mathrm{A} \beta$ binds different targets in a concentration-dependent manner (Mura et al., 2012; Zappettini et al., 2012). and, recently, it has been shown that $\mathrm{A} \beta$ directly affects $\alpha 7$-nAchR conformation and function by acting as an agonist when at picomolar concentrations or as an antagonist when at nanomolar concentrations (Lasala et al., 2019). It should be also considered that at high $\mathrm{A} \beta$ concentrations, the amount of oligomerization proportionally increases overrunning the physiological level (Gulisano et al., $2018 \mathrm{a}, \mathrm{b}$ ). This, in turn, might determine the interaction of $\mathrm{A} \beta$ oligomers with different targets, including APP (Puzzo et al., 2017).

These observations might be useful to understand the mechanisms switching the positive into the negative effects exerted by $\mathrm{oA} \beta$, and might be a basis for further studies to ensure novel, safe, and rational personalized therapeutic approaches to cure patients affected by AD.

\section{References}

Abramov E, Dolev I, Fogel H, Ciccotosto GD, Ruff E, Slutsky I (2009) Amyloid-beta as a positive endogenous regulator of release probability at hippocampal synapses. Nat Neurosci 12:1567-1576.

Aizenstein HJ, Nebes RD, Saxton JA, Price JC, Mathis CA, Tsopelas ND, Ziolko SK, James JA, Snitz BE, Houck PR, Bi W, Cohen AD, Lopresti BJ, DeKosky ST, Halligan EM, Klunk WE (2008) Frequent amyloid deposition without significant cognitive impairment among the elderly. Arch Neurol 65:1509-1517.

Antonova I, Arancio O, Trillat AC, Wang HG, Zablow L, Udo H, Kandel ER, Hawkins RD (2001) Rapid increase in clusters of presynaptic proteins at onset of long-lasting potentiation. Science 294:1547-1550.

Babits R, Szőke B, Sótonyi P, Rácz B (2016) Food restriction modifies ultrastructure of hippocampal synapses. Hippocampus 26:437-444.

Bakker A, Krauss GL, Albert MS, Speck CL, Jones LR, Stark CE, Yassa MA, Bassett SS, Shelton AL, Gallagher M (2012) Reduction of hippocampal hyperactivity improves cognition in amnestic mild cognitive impairment. Neuron 74:467-474.

Barone E, Tramutola A, Triani F, Calcagnini S, Di Domenico F, Ripoli C, Gaetani S, Grassi C, Butterfield DA, Cassano T, Perluigi M (2019) Biliverdin reductase-A mediates the beneficial effects of intranasal insulin in Alzheimer disease. Mol Neurobiol 56:2922-2943.

Bekinschtein P, Cammarota M, Igaz LM, Bevilaqua LR, Izquierdo I, Medina JH (2007) Persistence of long-term memory storage requires a late protein synthesis- and BDNF-dependent phase in the hippocampus. Neuron 53:261-277.

Bliss TV, Collingridge GL (1993) A synaptic model of memory: long-term potentiation in the hippocampus. Nature 361:31-39. 
Bollen E, Puzzo D, Rutten K, Privitera L, De Vry J, Vanmierlo T, Kenis G, Palmeri A, D'Hooge R, Balschun D, Steinbusch HM, Blokland A, Prickaerts J (2014) Improved long-term memory via enhancing cGMP-PKG signaling requires cAMP-PKA signaling. Neuropsychopharmacology 39:2497-2505.

Bon CL, Garthwaite J (2003) On the role of nitric oxide in hippocampal long-term potentiation. J Neurosci 23:1941-1948.

Bourne JN, Chirillo MA, Harris KM (2013) Presynaptic ultrastructural plasticity along CA3 $\rightarrow \mathrm{CA} 1$ axons during long-term potentiation in mature hippocampus. J Comp Neurol 521:3898-3912.

Bourtchuladze R, Frenguelli B, Blendy J, Cioffi D, Schutz G, Silva AJ (1994) Deficient long-term memory in mice with a targeted mutation of the cAMP-responsive element-binding protein. Cell 79:59-68.

Brody DL, Magnoni S, Schwetye KE, Spinner ML, Esparza TJ, Stocchetti N, Zipfel GJ, Holtzman DM (2008) Amyloid-beta dynamics correlate with neurological status in the injured human brain. Science 321:1221-1224.

Busche MA, Chen X, Henning HA, Reichwald J, Staufenbiel M, Sakmann B, Konnerth A (2012) Critical role of soluble amyloid- $\beta$ for early hippocampal hyperactivity in a mouse model of Alzheimer's disease. Proc Natl Acad Sci U S A 109:8740-8745.

Calabrese EJ (2001) Amyloid beta-peptide: biphasic dose responses. Crit Rev Toxicol 31:605-606.

Calabrese EJ (2008) Hormesis and medicine. Br J Clin Pharmacol 66: 594-617.

Caraci F, Gulisano W, Guida CA, Impellizzeri AA, Drago F, Puzzo D, Palmeri A (2015) A key role for TGF- $\beta 1$ in hippocampal synaptic plasticity and memory. Sci Rep 5:11252.

Cirrito JR, Yamada KA, Finn MB, Sloviter RS, Bales KR, May PC, Schoepp DD, Paul SM, Mennerick S, Holtzman DM (2005) Synaptic activity regulates interstitial fluid amyloid- $\beta$ levels in vivo. Neuron 48:913-922.

Cirrito JR, Kang JE, Lee J, Stewart FR, Verges DK, Silverio LM, Bu G, Mennerick S, Holtzman DM (2008) Endocytosis is required for synaptic activity-dependent release of amyloid-beta in vivo. Neuron 58:42-51.

Dawson GR, Seabrook GR, Zheng H, Smith DW, Graham S, O'Dowd G, Bowery BJ, Boyce S, Trumbauer ME, Chen HY, Van Der Ploeg LH, Sirinathsinghji DJ (1999) Age-related cognitive deficits, impaired longterm potentiation and reduction in synaptic marker density in mice lacking the $\beta$-amyloid precursor protein. Neuroscience 90:1-13.

DeFelipe J, Marco P, Busturia I, Merchán-Pérez A (1999) Estimation of the number of synapses in the cerebral cortex: methodological considerations. Cereb Cortex 9:722-732.

Deisseroth K, Bito H, Schulman H, Tsien RW (1995) Synaptic plasticity: a molecular mechanism for metaplasticity. Curr Biol 5:1334-1338.

Dobrunz LE, Stevens CF (1997) Heterogeneity of release probability, facilitation, and depletion at central synapses. Neuron 18:995-1008.

Fogel H, Frere S, Segev O, Bharill S, Shapira I, Gazit N, O’Malley T, Slomowitz E, Berdichevsky Y, Walsh DM, Isacoff EY, Hirsch JA, Slutsky I (2014) APP homodimers transduce an amyloid- $\beta$-mediated increase in release probability at excitatory synapses. Cell Rep 7:1560-1576.

Garcia-Osta A, Alberini CM (2009) Amyloid beta mediates memory formation. Learn Mem 16:267-272.

Geinisman Y (2000) Structural synaptic modifications associated with hippocampal LTP and behavioral learning. Cereb Cortex 10:952-962.

Ghosh A, Giese KP (2015) Calcium/calmodulin-dependent kinase II and Alzheimer's disease. Mol Brain 8:78.

Gulisano W, Maugeri D, Baltrons MA, Fà M, Amato A, Palmeri A, D'Adamio L, Grassi C, Devanand DP, Honig LS, Puzzo D, Arancio O (2018a) Role of amyloid- $\beta$ and tau proteins in Alzheimer's disease: confuting the amyloid cascade. J Alzheimers Dis 68:415.

Gulisano W, Melone M, Li Puma DD, Tropea MR, Palmeri A, Arancio O, Grassi C, Conti F, Puzzo D (2018b) The effect of amyloid- $\beta$ peptide on synaptic plasticity and memory is influenced by different isoforms, concentrations, and aggregation status. Neurobiol Aging 71:51-60.

Hardy J, Selkoe DJ (2002) The amyloid hypothesis of alzheimer's disease: progress and problems on the road to therapeutics. Science 297:353-356.

Herrup K (2015) The case for rejecting the amyloid cascade hypothesis. Nat Neurosci 18:794-799.

Huang EP (1998) Synaptic plasticity: Going through phases with LTP. Curr Biol 8:R350-R352.

Johnstone VP, Raymond CR (2011) A protein synthesis and nitric oxidedependent presynaptic enhancement in persistent forms of long-term potentiation. Learn Mem 18:625-633.
Kamenetz F, Tomita T, Hsieh H, Seabrook G, Borchelt D, Iwatsubo T, Sisodia S, Malinow R (2003) APP processing and synaptic function. Neuron 37:925-937.

Kleschevnikov AM, Sokolov MV, Kuhnt U, Dawe GS, Stephenson JD, Voronin LL (1997) Changes in paired-pulse facilitation correlate with induction of long-term potentiation in area CA1 of rat hippocampal slices. Neuroscience 76:829-843.

Koo EH, Park L, Selkoe DJ (1993) Amyloid $\beta$-protein as a substrate interacts with extracellular matrix to promote neurite outgrowth. Proc Natl Acad Sci U S A 90:4748-4752.

Koppensteiner P, Trinchese F, Fà M, Puzzo D, Gulisano W, Yan S, Poussin A, Liu S, Orozco I, Dale E, Teich AF, Palmeri A, Ninan I, Boehm S, Arancio O (2016) Time-dependent reversal of synaptic plasticity induced by physiological concentrations of oligomeric $\mathrm{A} \beta 42$ : an early index of $\mathrm{Alz}-$ heimer's disease. Sci Rep 6:32553.

Lasala M, Fabiani C, Corradi J, Antollini S, Bouzat C (2019) Molecular modulation of human $\alpha 7$ nicotinic receptor by amyloid- $\beta$ peptides. Front Cell Neurosci 13:37.

Lawrence JL, Tong M, Alfulaij N, Sherrin T, Contarino M, White MM, Bellinger FP, Todorovic C, Nichols RA (2014) Regulation of presynaptic $\mathrm{Ca} 2+$, synaptic plasticity and contextual fear conditioning by a $\mathrm{N}$-terminal $\beta$-amyloid fragment. J Neurosci 34:14210-14218.

Lazarevic V, Fieńko S, Andres-Alonso M, Anni D, Ivanova D, MontenegroVenegas C, Gundelfinger ED, Cousin MA, Fejtova A (2017) Physiological concentrations of amyloid beta regulate recycling of synaptic vesicles via alpha7 acetylcholine receptor and CDK5/calcineurin signaling. Front Mol Neurosci 10:221.

Lesné SE, Sherman MA, Grant M, Kuskowski M, Schneider JA, Bennett DA, Ashe KH (2013) Brain amyloid- $\beta$ oligomers in ageing and Alzheimer's disease. Brain 136:1383-1398.

Leutgeb JK, Frey JU, Behnisch T (2005) Single cell analysis of activitydependent cyclic AMP-responsive element-binding protein phosphorylation during long-lasting long-term potentiation in area CAl of mature rat hippocampal-organotypic cultures. Neuroscience 131:601-610.

Lisman J, Yasuda R, Raghavachari S (2012) Mechanisms of CaMKII action in long-term potentiation. Nat Rev Neurosci 13:169-182.

Lorenzo A, Yuan M, Zhang Z, Paganetti PA, Sturchler-Pierrat C, Staufenbiel M, Mautino J, Vigo FS, Sommer B, Yankner BA (2000) Amyloid beta interacts with the amyloid precursor protein: a potential toxic mechanism in Alzheimer's disease. Nat Neurosci 3:460-464

Lu YF, Kandel ER, Hawkins RD (1999) Nitric oxide signaling contributes to late-phase LTP and CREB phosphorylation in the hippocampus. J Neurosci 19:10250-10261.

Maarouf CL, Daugs ID, Kokjohn TA, Walker DG, Hunter JM, Kruchowsky JC, Woltjer R, Kaye J, Castaño EM, Sabbagh MN, Beach TG, Roher AE (2011) Alzheimer's disease and non-demented high pathology control nonagenarians: comparing and contrasting the biochemistry of cognitively successful aging. PLoS One 6:e27291.

Mattson MP (2008) Hormesis defined. Ageing Res Rev 7:1-7.

Melone M, Bellesi M, Ducati A, Iacoangeli M, Conti F (2011) Cellular and synaptic localization of EAAT2a in human cerebral cortex. Front Neuroanat 4:151.

Melone M, Ciappelloni S, Conti F (2015) A quantitative analysis of cellular and synaptic localization of GAT-1 and GAT-3 in rat neocortex. Brain Struct Funct 220:885-897.

Morley JE, Farr SA, Banks WA, Johnson SN, Yamada KA, Xu L (2010) A physiological role for amyloid-beta protein:enhancement of learning and memory. J Alzheimers Dis 19:441-449.

Mura E, Zappettini S, Preda S, Biundo F, Lanni C, Grilli M, Cavallero A, Olivero G, Salamone A, Govoni S, Marchi M (2012) Dual effect of betaamyloid on $\alpha 7$ and $\alpha 4 \beta 2$ nicotinic receptors controlling the release of glutamate, aspartate and GABA in rat hippocampus. PLoS One 7:e29661.

Nguyen PV, Abel T, Kandel ER (1994) Requirement of a critical period of transcription for induction of a late phase of LTP. Science 265:1104-1107.

Opazo P, Viana da Silva S, Carta M, Breillat C, Coultrap SJ, Grillo-Bosch D, Sainlos M, Coussen F, Bayer KU, Mulle C, Choquet D (2018) CaMKII metaplasticity drives $\mathrm{A} \beta$ oligomer-mediated synaptotoxicity. Cell Rep 23: 3137-3145.

Padayachee ER, Whiteley CG (2011) Spectrofluorimetric analysis of the interaction of amyloid peptides with neuronal nitric oxide synthase: implications in Alzheimer's disease. Biochim Biophys Acta 1810:1136-1140.

Palmeri A, Ricciarelli R, Gulisano W, Rivera D, Rebosio C, Calcagno E, Tro- 
pea MR, Conti S, Das U, Roy S, Pronzato MA, Arancio O, Fedele E, Puzzo D (2017) Amyloid- $\beta$ peptide is needed for cGMP-induced long-term potentiation and memory. J Neurosci 37:6926-6937.

Parodi J, Sepúlveda FJ, Roa J, Opazo C, Inestrosa NC, Aguayo LG (2010) Beta-amyloid causes depletion of synaptic vesicles leading to neurotransmission failure. J Biol Chem 285:2506-2514.

Pearson HA, Peers C (2006) Physiological roles for amyloid beta peptides. J Physiol 575:5-10.

Peters A, Palay SL, deF Webster H (1991) The fine structure of the nervous system neurons and their supportive cells. New York: OUP.

Picciotto MR, Caldarone BJ, King SL, Zachariou V (2000) Nicotinic receptors in the brain. Links between molecular biology and behavior. Neuropsychopharmacology 22:451-465.

Pozzo-Miller LD, Gottschalk W, Zhang L, McDermott K, Du J, Gopalakrishnan R, Oho C, Sheng ZH, Lu B (1999) Impairments in high-frequency transmission, synaptic vesicle docking, and synaptic protein distribution in the hippocampus of BDNF knockout mice. J Neurosci 19:4972-4983.

Prickaerts J, Van Goethem NP, Gulisano W, Argyrousi EK, Palmeri A, Puzzo D (2017) Physiological and pathological processes of synaptic plasticity and memory in drug discovery: do not forget the dose-response curve. Eur J Pharmacol 817:59-70.

Puzzo D, Vitolo O, Trinchese F, Jacob JP, Palmeri A, Arancio O (2005) Amyloid-beta peptide inhibits activation of the nitric oxide/cGMP/ cAMP-responsive element-binding protein pathway during hippocampal synaptic plasticity. J Neurosci 25:6887-6897.

Puzzo D, Privitera L, Leznik E, Fà M, Staniszewski A, Palmeri A, Arancio O (2008) Picomolar amyloid-beta positively modulates synaptic plasticity and memory in hippocampus. J Neurosci 28:14537-14545.

Puzzo D, Staniszewski A, Deng SX, Privitera L, Leznik E, Liu S, Zhang H, Feng Y, Palmeri A, Landry DW, Arancio O (2009) Phosphodiesterase 5 inhibition improves synaptic function, memory, and amyloid-beta load in an Alzheimer's disease mouse model. J Neurosci 29:8075-8086.

Puzzo D, Privitera L, Fa' M, Staniszewski A, Hashimoto G, Aziz F, Sakurai M, Ribe EM, Troy CM, Mercken M, Jung SS, Palmeri A, Arancio O (2011) Endogenous amyloid- $\beta$ is necessary for hippocampal synaptic plasticity and memory. Ann Neurol 69:819-830.

Puzzo D, Privitera L, Palmeri A (2012) Hormetic effect of amyloid- $\beta$ peptide in synaptic plasticity and memory. Neurobiol Aging 33:1484.e15-24.

Puzzo D, Gulisano W, Arancio O, Palmeri A (2015) The keystone of Alzheimer pathogenesis might be sought in $A \beta$ physiology. Neuroscience 307:26-36.

Puzzo D, Fiorito J, Purgatorio R, Gulisano W, Palmeri A, Arancio O, Nicholls R (2016) Molecular mechanisms of learning and memory. In: Genes, Environment and Alzheimer's Disease (Lazarov O, Tesco G, ed), pp 1-28. Oxford: Academic Press.

Puzzo D, Piacentini R, Fá M, Gulisano W, Li Puma DD, Staniszewski A, Zhang H, Tropea MR, Cocco S, Palmeri A, Fraser P, D’Adamio L, Grassi C, Arancio O (2017) LTP and memory impairment caused by extracellular A $\beta$ and Tau oligomers is APP-dependent. eLife 6:e26991.

Redondo RL, Morris RG (2011) Making memories last: the synaptic tagging and capture hypothesis. Nat Rev Neurosci 12:17-30.

Ripoli C, Piacentini R, Riccardi E, Leone L, Li Puma DD, Bitan G, Grassi C (2013) Effects of different amyloid $\beta$-protein analogues on synaptic function. Neurobiol Aging 34:1032-1044.

Ripoli C, Cocco S, Li Puma DD, Piacentini R, Mastrodonato A, Scala F, Puzzo D, D’Ascenzo M, Grassi C (2014) Intracellular accumulation of amyloid- $\beta(\mathrm{A} \beta)$ protein plays a major role in $\mathrm{A} \beta$-induced alterations of glutamatergic synaptic transmission and plasticity. J Neurosci 34: 12893-12903.

Russell CL, Semerdjieva S, Empson RM, Austen BM, Beesley PW, Alifragis P (2012) Amyloid- $\beta$ acts as a regulator of neurotransmitter release disrupting the interaction between synaptophysin and VAMP2. PLoS One 7:e43201.

Sasaki M, Gonzalez-Zulueta M, Huang H, Herring WJ, Ahn S, Ginty DD, Dawson VL, Dawson TM (2000) Dynamic regulation of neuronal NO synthase transcription by calcium influx through a CREB family transcription factor-dependent mechanism. Proc Natl Acad Sci U S A 97:8617-8622.

Schmidt SD, Nixon RA, Mathews PM (2005) ELISA method for measurement of amyloid- $\beta$ levels. In: Amyloid proteins (Sigurdsson EM, ed), pp 279-298. Totowa, NJ: Humana.

Schneider CA, Rasband WS, Eliceiri KW (2012) NIH Image to ImageJ: 25 years of image analysis. Nat Methods 9:671-675.

Shaked GM, Kummer MP, Lu DC, Galvan V, Bredesen DE, Koo EH (2006) Abeta induces cell death by direct interaction with its cognate extracellular domain on APP (APP 597-624). FASEB J 20:1254-1256.

Shepherd GM, Harris KM (1998) Three-dimensional structure and composition of CA3->CA1 axons in rat hippocampal slices: implications for presynaptic connectivity and compartmentalization. J Neurosci 18 : $8300-8310$

Song JH, Yu JT, Tan L (2015) Brain-derived neurotrophic factor in Alzheimer's disease: risk, mechanisms, and therapy. Mol Neurobiol 52: 1477-1493.

Spinelli M, Fusco S, Mainardi M, Scala F, Natale F, Lapenta R, Mattera A, Rinaudo M, Li Puma DD, Ripoli C, Grassi A, D’Ascenzo M, Grassi C (2017) Brain insulin resistance impairs hippocampal synaptic plasticity and memory by increasing GluA1 palmitoylation through FoxO3a. Nat Commun 8:2009.

Stine WB Jr, Dahlgren KN, Krafft GA, LaDu MJ (2003) In vitro characterization of conditions for amyloid-beta peptide oligomerization and fibrillogenesis. J Biol Chem 278:11612-11622.

Tyan SH, Shih AY, Walsh JJ, Maruyama H, Sarsoza F, Ku L, Eggert S, Hof PR, Koo EH, Dickstein DL (2012) Amyloid precursor protein (APP) regulates synaptic structure and function. Mol Cell Neurosci 51:43-52.

Venturini G, Colasanti M, Persichini T, Fioravanti E, Ascenzi P, Palomba L, Cantoni O, Musci G (2002) Beta-amyloid inhibits NOS activity by subtracting NADPH availability. FASEB J 16:1970-1972.

Wang HY, Lee DH, Davis CB, Shank RP (2000) Amyloid peptide Abeta(142) binds selectively and with picomolar affinity to alpha7 nicotinic acetylcholine receptors. J Neurochem 75:1155-1161.

Wang Z, Jackson RJ, Hong W, Taylor WM, Corbett GT, Moreno A, Liu W, Li S, Frosch MP, Slutsky I, Young-Pearse TL, Spires-Jones TL, Walsh DM (2017) Human brain-derived $A \beta$ oligomers bind to synapses and disrupt synaptic activity in a manner that requires APP. J Neurosci 37: 11947-11966.

Zappettini S, Grilli M, Olivero G, Mura E, Preda S, Govoni S, Salamone A, Marchi M (2012) Beta amyloid differently modulate nicotinic and muscarinic receptor subtypes which stimulate in vitro and in vivo the release of glycine in the rat hippocampus. Front Pharmacol 3:146.

Zucker RS, Regehr WG (2002) Short-term synaptic plasticity. Annu Rev Physiol 64:355-405. 